\title{
Middle atmospheric ozone, nitrogen dioxide and nitrogen trioxide in 2002-2011: SD-WACCM simulations compared to GOMOS observations
}

\author{
Erkki Kyrölä $^{1}$, Monika E. Andersson ${ }^{1}$, Pekka T. Verronen ${ }^{1}$, Marko Laine ${ }^{2}$, Simo Tukiainen ${ }^{3}$, and Daniel R. Marsh ${ }^{4}$ \\ ${ }^{1}$ Earth Observation Research, Space and Earth Observation Centre, Finnish Meteorological Institute, P.O. Box 503, \\ 00101 Helsinki, Finland \\ ${ }^{2}$ Meteorological Research, Meteorological and Marine Research Programme, Finnish Meteorological Institute, P.O. Box 503, \\ 00101 Helsinki, Finland \\ ${ }^{3}$ Atmospheric Composition Research, Climate Research Programme, Finnish Meteorological Institute, P.O. Box 503, \\ 00101 Helsinki, Finland \\ ${ }^{4}$ National Center for Atmospheric Research, Boulder, Colorado, USA
}

Correspondence: Erkki Kyrölä (erkki.kyrola@fmi.fi)

Received: 11 December 2017 - Discussion started: 20 December 2017

Revised: 21 March 2018 - Accepted: 21 March 2018 - Published: 12 April 2018

\begin{abstract}
Most of our understanding of the atmosphere is based on observations and their comparison with model simulations. In middle atmosphere studies it is common practice to use an approach, where the model dynamics are at least partly based on temperature and wind fields from an external meteorological model. In this work we test how closely satellite measurements of a few central trace gases agree with this kind of model simulation. We use collocated vertical profiles where each satellite measurement is compared to the closest model data.

We compare profiles and distributions of $\mathrm{O}_{3}, \mathrm{NO}_{2}$ and $\mathrm{NO}_{3}$ from the Global Ozone Monitoring by Occultation of Stars instrument (GOMOS) on the Envisat satellite with simulations by the Whole Atmosphere Community Climate Model (WACCM). GOMOS measurements are from nighttime. Our comparisons show that in the stratosphere outside the polar regions differences in ozone between WACCM and GOMOS are small, between 0 and 6\%. The correlation of 5-day time series show a very high $0.9-0.95$. In the tropical region $10^{\circ} \mathrm{S}-10^{\circ} \mathrm{N}$ below $10 \mathrm{hPa}$ WACCM values are up to $20 \%$ larger than GOMOS. In the Arctic below $6 \mathrm{hPa}$ WACCM ozone values are up to $20 \%$ larger than GOMOS. In the mesosphere between 0.04 and $1 \mathrm{hPa}$ the WACCM is at most $20 \%$ smaller than GOMOS. Above the ozone minimum at $0.01 \mathrm{hPa}($ or $80 \mathrm{~km})$ large differences are found between WACCM and GOMOS. The correlation can still be high, but
\end{abstract}

at the second ozone peak the correlation falls strongly and the ozone abundance from WACCM is about $60 \%$ smaller than that from GOMOS. The total ozone columns (above $50 \mathrm{hPa}$ ) of GOMOS and WACCM agree within $\pm 2 \%$ except in the Arctic where WACCM is $10 \%$ larger than GOMOS.

Outside the polar areas and in the validity region of GOMOS $\mathrm{NO}_{2}$ measurements $(0.3-37 \mathrm{hPa})$ WACCM and GOMOS $\mathrm{NO}_{2}$ agree within -5 to $+25 \%$ and the correlation is high (0.7-0.95) except in the upper stratosphere at the southern latitudes. In the polar areas, where solar particle precipitation and downward transport from the thermosphere enhance $\mathrm{NO}_{2}$ abundance, large differences up to $-90 \%$ are found between WACCM and GOMOS $\mathrm{NO}_{2}$ and the correlation varies between 0.3 and 0.9 . For $\mathrm{NO}_{3}$, we find that the WACCM and GOMOS difference is between -20 and $5 \%$ with a very high correlation of $0.7-0.95$. We show that $\mathrm{NO}_{3}$ values strongly depend on temperature and the dependency can be fitted by the exponential function of temperature. The ratio of $\mathrm{NO}_{3}$ to $\mathrm{O}_{3}$ from WACCM and GOMOS closely follow the prediction from the equilibrium chemical theory. Abrupt temperature increases from sudden stratospheric warmings (SSWs) are reflected as sudden enhancements of WACCM and GOMOS $\mathrm{NO}_{3}$ values. 


\section{Introduction}

The quality of atmospheric modelling is crucial for making reliable predictions regarding future climate. The minimum quality requirement for any model is that previously measured central atmospheric variables can be simulated with reasonable accuracy. The increasing number of global satellite missions since the discovery of the ozone hole offers a good opportunity to compare models with observed data. Various satellite measurements of trace gases are traditionally compared with validating ground-based instruments (see e.g. Hubert et al., 2016), but they are now also increasingly compared with each other (see e.g. Hegglin and Tegtmeier, 2017; Tegtmeier et al., 2013). This activity has led to an improved understanding of the accuracy of satellite measurements which is an essential ingredient for a modelmeasurement comparison.

In this work, we make use of the Whole Atmosphere Community Climate Model (WACCM) from the National Center for Atmospheric Research and compare its results to satellite observations from the Global Ozone Monitoring by Occultation of Stars instrument (GOMOS). We concentrate on an atmospheric region ranging from the stratosphere to lower thermosphere $(20-100 \mathrm{~km})$ and on three important minor constituents $\mathrm{O}_{3}, \mathrm{NO}_{2}$ and $\mathrm{NO}_{3}$ measured by GOMOS.

Ozone is a central chemical element in the middle atmosphere and essential for stopping short wave UV light from entering the biosphere. Ozone has diurnal variability, which in the stratosphere is weak, but at 90-95 km nighttime ozone can be an order of magnitude more abundant than during daytime (see e.g. Kyrölä et al., 2010a; Smith et al., 2013). Measured satellite ozone profiles are validated using ozone sondes and ozone lidars (see e.g. Hubert et al., 2016). Comparisons to other satellite measurements also help to establish the data quality. Nitrogen dioxide, as a member of the odd nitrogen family, participates in the catalytic destruction of ozone especially in the upper stratosphere (Lary, 1997). In polar areas precipitation of charged particles creates a vast amount of $\mathrm{NO}_{x}$ which has a long chemical lifetime in the polar darkness. When isolated by a stable vortex, enhanced $\mathrm{NO}_{x}$ can descend into the upper stratosphere, which then leads to natural ozone loss when $\mathrm{NO}_{x}$ becomes illuminated by increasing solar light after the winter season (e.g. Seppälä et al., 2007; Päivärinta et al., 2016). Polar $\mathrm{NO}_{x}$ is also enhanced by polar descent from the thermosphere and exceptionally large increases have been measured after so-called sudden stratospheric warming events (SSWs) where the vortex structure is disturbed (see for example, Hauchecorne et al., 2007; Randall et al., 2009; Smith et al., 2009; Sofieva et al., 2012; Chandran and Collins, 2014). Nitrogen trioxide is a part of the $\mathrm{O}_{3}-\mathrm{NO}_{2}-\mathrm{NO}$ chemistry, has a very strong diurnal variation at all altitudes and is almost absent during daytime (see e.g. Hauchecorne et al., 2005).

WACCM is the atmospheric component of the Community Earth System Model (CESM) (Neale et al., 2013). WACCM is a chemistry-climate model spanning the range of altitude from Earth's surface to the lower thermosphere (approximately $140 \mathrm{~km}$ ) with 88 vertical levels of variable vertical resolution of $1.1 \mathrm{~km}$ in the troposphere to $3.5 \mathrm{~km}$ above $65 \mathrm{~km}$ (Marsh et al., 2013). The model's horizontal resolution is $1.9^{\circ}$ latitude by $2.5^{\circ}$ longitude and the model time step is $30 \mathrm{~min}$. In the present analysis version 4 of WACCM was run in specified dynamics mode by constraining dynamical fields to Modern-Era Retrospective Analysis for Research and Applications (MERRA) meteorological reanalyses below $1 \mathrm{hPa}$. Above the stratopause WACCM dynamics are solved in a free running mode, i.e. temperature and dynamic fields are self-determined (although in practice they are still strongly modulated by MERRA). The version of WACCM used in this work includes chemistry of the lower, D-region ionosphere with 307 reactions of 20 positive ions and 21 negative ions (see Verronen et al., 2016).

WACCM has been evaluated in many modelmeasurement intercomparison studies. In Eyring et al. (2010) and Eyring et al. (2013), WACCM's total ozone values and trends were shown to be in reasonable agreement with satellite observations. Total ozone biases from different latitude ranges were between -5.5 and $2.3 \%$. Comparisons at specific atmospheric conditions have provided more information on the agreement between WACCM trace gas profiles and observations. In Tweedy et al. (2013), the simulated behaviour of the secondary ozone maximum is compared against SABER measurements during a major sudden warming. The behaviour during SSWs was found to be similar while the nighttime ozone amount is generally underestimated by about a factor of 2 in WACCM. Comparisons of $\mathrm{NO}_{x}$ during polar winter, when $\mathrm{NO}_{x}$ is influenced by energetic particle precipitation, have been made in many studies (Jackman et al., 2011; Funke et al., 2011; Randall et al., 2015; Andersson et al., 2016; Funke et al., 2017). From these studies it seems that WACCM tends to underestimate mesospheric $\mathrm{NO}_{x}$ by a factor of approximately 4 .

GOMOS (Bertaux et al., 2010) was an instrument on the European Space Agency's Envisat satellite which was in operation for just over 10 years between 2002 and 2012. The measurement method of GOMOS, stellar occultation, uses light from the 180 brightest stars allowing global coverage of measurements with good vertical resolution $(2-3 \mathrm{~km}$ for ozone, $4 \mathrm{~km}$ for $\mathrm{NO}_{2}$ and $\mathrm{NO}_{3}$ ). The occultation method is self-calibrating because the occulted star's spectrum is also measured without atmospheric intervention and therefore the primary source data for retrievals (i.e. transmissions) are, in principle, stable. GOMOS measured 880000 stellar occultations during the lifetime of Envisat. Ozone's relatively large abundance makes it quite an easily observable constituent from satellite instruments using optical measurements. GOMOS measurements can be used to retrieve ozone at altitudes ranging from the troposphere to the lower thermosphere. $\mathrm{NO}_{2}$ and $\mathrm{NO}_{3}$ can be retrieved in the stratosphere. 
Our comparisons of GOMOS measurements with WACCM simulations will be based on of individual, co-located profile measurements, whereas in many other model-data studies climatological or other average quantities are used. Our method avoids the problem of uneven (in geolocation and time) sampling that accompanies limb and especially limb occultation measurements and distorts climatologies. In the Coupled Model Intercomparison Project (CMIP) and in the more specialised Chemistry-Climate Model Initiative (CCMI) several atmospheric (or more generally earth system) models including CESM/WACCM have been compared with each other and also with observations (see Tilmes et al., 2016; Morgenstern et al., 2017; Eyring et al., 2010, 2013). Most of these studies were interested in targeting on future climate projections especially in the troposphere. In this work we are interested in seeing how well a model simulates the whole middle atmosphere from the upper troposphere to the lower thermosphere in a limited time range 2002-2011.

Our study is structured as follows. In Sect. 2 we introduce the GOMOS instrument and the measurements we are using in this work. In Sect. 3 the main properties of the WACCM model are introduced. The comparison method is introduced in Sect. 4 and individual comparisons of $\mathrm{O}_{3}, \mathrm{NO}_{2}$ and $\mathrm{NO}_{3}$ are presented in Sects. 5-7.

\section{GOMOS measurements}

GOMOS was a stellar occultation instrument on board Envisat that was operational from 2002 to 2012 (for GOMOS overviews, see Bertaux et al., 2010; ESA, 2001, and https://earth.esa.int/web/guest/missions/ esa-operational-eo-missions/envisat/instruments/gomos).

GOMOS measured occultations during both day and night. However, here we use only GOMOS nighttime occultations. Measurements made during daytime suffer from scattered solar light, which leads to a low signal-to-noise ratio of the stellar signal. Daytime data have problems especially below $55 \mathrm{~km}$, and the quality depends very strongly on the properties of the GOMOS target star (Verronen et al., 2007). An alternative approach to retrieve ozone during daytime is to use the scattered solar light observed by GOMOS, this method works well in the stratosphere and lower mesosphere (Tukiainen et al., 2011, 2015). But as mentioned above, we restrict our analysis to nighttime occultation data, partly because they provide an altitude coverage from stratosphere to lower thermosphere for ozone.

GOMOS nighttime profiles of $\mathrm{O}_{3}, \mathrm{NO}_{2}$ and $\mathrm{NO}_{3}$ are retrieved from the spectral range 248 to $690 \mathrm{~nm}$. The integration time of the measurements is $0.5 \mathrm{~s}$, which provides an altitude sampling resolution of $0.2-1.6 \mathrm{~km}$ depending on the tangent altitude and the azimuth angle of the measurement. The retrieved ozone profiles have a $2 \mathrm{~km}$ vertical resolution below $30 \mathrm{~km}$ and a $3 \mathrm{~km}$ resolution above $40 \mathrm{~km}$, whereas
$\mathrm{NO}_{2}$ and $\mathrm{NO}_{3}$ have a $4 \mathrm{~km}$ vertical resolution at all altitudes. Details of the GOMOS retrieval algorithms and data quality are discussed in Kyrölä et al. (2010b) and Tamminen et al. (2010). In this work we use GOMOS data from the ESA processing version 6 in a vertically gridded form (for data access, see data availability section). We remove data points that have been measured when Envisat was located in the region of the South Atlantic Anomaly. The illumination conditions for the GOMOS measurements are determined by two solar zenith angles controlling solar light at the tangent point and at the satellite location. At the tangent point we require that the zenith angle is greater than $104^{\circ}$. It has been shown that for zenith angles smaller than $118^{\circ}$ at the satellite position some stray light can be present, but we have not found any discernible change in our results ignoring this restriction altogether. In the GOMOS gridded ozone data there is an ozone-specific flag that screens stars that do not provide sufficient signal-to-noise ratio for reliable ozone retrieval in the mesosphere-lower thermosphere (faint and cool stars). Profiles considered as outliers either in the stratosphere or in the mesosphere are also flagged. We only use those profiles where all three flags are equal to zero. The total number of GOMOS nighttime measurements is then 238664 . For $\mathrm{NO}_{2}$ and $\mathrm{NO}_{3}$ the ozone flags can be ignored and we get 377881 measurements. The number of measurements peaked in 2004 and declined thereafter due to the problems connected to the steering mechanism of the instrument. During 2005 no measurements were collected from the period between February and May due to this steering problem. Note that the polar regions are not covered by nighttime measurements during summer months. For other latitudes measurements cover all seasons.

The first comprehensive validation of GOMOS nighttime stratospheric ozone (ESA data version 4) against ground-based and balloon-borne instruments was presented in Meijer et al. (2004). The results showed that GOMOS nighttime ozone agrees within a few percent with the correlative data (sondes and lidars) in the stratosphere outside polar areas. An update of this work was issued by van Gijsel et al. (2010) using the ESA software version 5 and results were similar to Meijer et al. (2004). In this work we are using the ESA software version 6. All three versions (4-6) provide very similar results. Version 6 has been under validation in the ESA projects Valid-2 and Multi-TASTE and the validation reports are available from https://earth.esa.int/web/sppa/mission-performance/ esa-missions/envisat/gomos/cal-val/validation-activities.

Recent similar validation results can be found from Hubert et al. (2016) and Sofieva et al. (2017). Results show differences to be within $\pm 3 \%$ between 20 and $45 \mathrm{~km}$. Below $20 \mathrm{~km}$ GOMOS ozone data show increasing positive bias in the tropics, but in this work we restrict analysis to higher altitudes where such bias is not observed. GOMOS and SAGE II, the so-called gold standard of satellite ozone profiles, were compared in Kyrölä et al. (2013) and differences 
within $\pm 4 \%$ in $23-55 \mathrm{~km}$ were observed when the SAGE II sunrise and sunset occultations were treated separately. The diurnal variation of ozone in the stratosphere and some sunset-sunrise instrumental factors contribute to these numbers (see also Sakazaki et al., 2015). Climatological comparisons of several limb viewing satellite instruments including GOMOS are presented in Tegtmeier et al. (2013).

GOMOS is able to measure ozone up to $100 \mathrm{~km}$ when stars with sufficiently high effective temperature are used. For mesospheric heights there are no real validation results, but we can get some insight from comparisons to other satellite measurements. In Verronen et al. (2005) GOMOS and MIPAS ozone were found to agree within $\pm 10 \%$ in $25-70 \mathrm{~km}$; similar results were obtained in Ceccherini et al. (2008). SABER and GOMOS were compared in Smith et al. (2008, 2013), which showed that GOMOS nighttime mesospheric ozone values are about $20 \%$ lower than SABER.

GOMOS measurements can nominally be used to retrieve $\mathrm{NO}_{2}$ at altitudes between 25 and $50 \mathrm{~km}$, while in the polar regions altitudes up to about $70 \mathrm{~km}$ can be reached during winter months due to higher $\mathrm{NO}_{2}$ concentrations. There is only one publication where GOMOS $\mathrm{NO}_{2}$ measurements have been compared with in situ measurements. This was carried out via a comparison with balloon-borne instruments (Renard et al., 2008), which indicated an agreement within $\pm 25 \%$. In addition, several comparisons against satellitebased observations have been made. Verronen et al. (2009) found that GOMOS $\mathrm{NO}_{2}$ values are $10-25 \%$ higher than MIPAS. Comparison with ACE-FTS in Sheese et al. (2016) showed better than $10 \%$ agreement between 23 and $30 \mathrm{~km}$ and $\sim 25 \%$ between 30 and $45 \mathrm{~km}$. At higher altitudes larger differences were found, but the necessary correction for diurnal variation made results very uncertain. Nitrogen dioxide has a strong diurnal variation with maximum and minimum amounts seen during early night and early morning, respectively (for diurnal cycle from model simulations, see e.g. Brasseur and Solomon (2005) and Kyrölä et al. (2010a). Climatological comparison with HALOE can be found in Hauchecorne et al. (2005).

GOMOS retrieval of $\mathrm{NO}_{3}$ covers the altitude range 25$50 \mathrm{~km}$. During daytime $\mathrm{NO}_{3}$ almost vanishes via photolysis but rises quickly after sunset from the reactions between $\mathrm{O}_{3}$ and $\mathrm{NO}_{2}$ (for diurnal cycle from model simulations, see e.g. Brasseur and Solomon, 2005; Kyrölä et al., 2010a). There are only few $\mathrm{NO}_{3}$ measurements to which to compare GOMOS measurements. GOMOS $\mathrm{NO}_{3}$ have been compared with two balloon measurements in Renard et al. (2008), but with inconclusive results. In Hakkarainen et al. (2012) GOMOS measurements were compared with SAGE III lunar measurements and the agreement was found to be within $\pm 25 \%$.

\section{SD-WACCM-D simulations}

WACCM includes the $\mathrm{O}_{x}, \mathrm{NO}_{x}, \mathrm{Cl}_{x}$ and $\mathrm{BrO}$ families and $\mathrm{CH}_{4}$ with its reaction products. The number of reactions is 217 with 59 species. Heterogeneous reactions with three types of aerosols are also included. The model includes orographic and non-orographic gravity waves (see Garcia et al., 2007). The upper boundary temperature condition is given by the MSIS-model by Hedin (1991). The same model is used to specify $\mathrm{O}, \mathrm{O}_{2}, \mathrm{H}$ and $\mathrm{N}$ upper boundary conditions. At the lower boundary observations are used to specify the surface mixing ratios of CFC gases, $\mathrm{CH}_{3}, \mathrm{~N}_{2} \mathrm{O}$ and other important gases for stratospheric processes. Historical surface concentrations of greenhouse gases were taken from Meinshausen et al. (2011). The solar irradiance is provided by the model of Lean et al. (2005) which takes the spectral and flux variations during the solar cycle into account. WACCM includes ionisation rates from solar proton events (SPEs) and auroral electrons. More details of the WACCM model can be found from Marsh et al. (2013), Smith et al. (2011) and Garcia et al. (2007).

In this work we use SD-WACCM-D version 4, meaning that the model (a) includes chemistry of the lower, D-region ionosphere required for detailed energetic particle precipitation (EPP) simulations (see Verronen et al., 2016) and (b) is run in specified dynamics (SD) mode by constraining dynamical fields below $1 \mathrm{hPa}$ to Modern-Era Retrospective Analysis for Research and Applications (MERRA) meteorological reanalyses (see Rienecker et al., 2011). SD mode allows for realistic representation of atmospheric dynamics making the simulations directly comparable to satellite observations, while the D-region ion chemistry has been shown to improve the polar mesospheric comparisons for many species, including $\mathrm{NO}_{x}$ (Andersson et al., 2016). In order to provide an ion source for the low-latitude D-region chemistry, ionisation due to galactic cosmic radiation is included in our simulations using the Nowcast of Atmospheric Ionising Radiation for Aviation Safety (NAIRAS) model (for details, see Jackman et al., 2016). For this study, we also include the ionisation due to $30-1000 \mathrm{keV}$ radiation belt electron precipitation in the energetic particle forcing. For details on the precipitation model and ionisation rate calculation, see van de Kamp et al. (2016). In this energy range, electrons add to $\mathrm{HO}_{x}$ and $\mathrm{NO}_{x}$ production in situ at $60-90 \mathrm{~km}$ altitude, directly affecting mesospheric ozone chemistry at geomagnetic latitudes between 55 and $72^{\circ}$ (Matthes et al., 2017; Andersson et al., 2018). The ionisation rates are applied in WACCM as daily, zonal mean values which depend on the geomagnetic $A_{p}$ index and latitude. 


\section{Comparison method}

In order to compare GOMOS vertical profiles with WACCM simulations each satellite measurement is paired with the closest WACCM latitude-longitude-time profile (i.e. no interpolation between different WACCM grid cells is done). The geolocation of the satellite measurement is defined by the average value when the line-of-sight of the instrument is between 20 and $50 \mathrm{~km}$ in altitude. In this study, we compare all GOMOS nighttime measurements from 2002 to 2011 to a WACCM simulation run for the same period. For the satellite measurements the comparison is complete in the sense that every measurement finds its model partner with very good co-location limits: latitude difference smaller than $0.95^{\circ}$, longitude difference smaller than $1.25^{\circ}$ and time difference shorter than $15 \mathrm{~min}$. This method avoids the problem of uneven (in geolocation and time) sampling that accompanies limb and especially limb occultation measurements and which may distort trace gas climatologies and their comparisons.

A retrieved GOMOS constituent profile is given at the measurement's refracted line-of-sight altitudes that vary from one measurement to another. In this work we interpolate (linearly) the profiles to a regular geometric altitude grid with $1 \mathrm{~km}$ step. GOMOS constituent abundances are given in number densities. WACCM runs on a pressure grid and abundances are mixing ratios. In order to compare satellite measurements with WACCM we need to either change satellite measurements to the pressure grid of WACCM or to change WACCM results to the altitude grid used by satellite data. We have selected to work using the WACCM's pressure grid; therefore, every GOMOS measurement is interpolated to the altitudes obtained from the geopotential heights of the WACCM's latitude-longitude cell nearest to the satellite measurement at the time of the measurement. This brings the number densities of satellites to the pressure grid of the model. In this work we show results in mixing ratios as they more suitable for illustrating results. The transformation to mixing ratios is accomplished by the neutral density distribution of WACCM (originating in the SD-version from MERRA and internal dynamics).

The method we use for comparing collocated satellite and WACCM profiles and their differences at each altitude $z$ is to calculate the bias over a suitable number of profiles in a selected region (time and geolocation) as

$B(z)=\left\langle f_{k}^{\mathrm{W}}(z)-f_{k}^{\mathrm{G}}(z)\right\rangle$,

where $f_{k}^{\mathrm{W}}$ denotes WACCM and $f_{\mathrm{k}}^{G}$ GOMOS collocated vertical profiles. Satellite gridded profiles have some missing data from flagged data points or from restrictions of the altitude coverage of measurements. The corresponding WACCM data points are ignored in the average in order to preserve the complete correspondence of the data sets. For practical reasons we will also use the bias in a relative sense as
$\Delta(z)=100 \% \frac{B(z)}{\left\langle f_{k}^{\mathrm{G}}(z)\right\rangle}$.

The scaling factor (denominator) is calculated from GOMOS in the same region as the bias.

Calculation of the average estimates is based on dividing spatial and temporal extensions to suitable scales. We average data within $10^{\circ}$ in latitude and use zonal averaging. For the polar regions we also show results from a larger latitudinal range (from 60 to $90^{\circ}$ south and north). In the time domain the analysis is based on 5-day time averaging in order to capture fast polar processes while keeping reasonable statistical accuracy.

The average from the averaging region and period of time is done by first making averages for each available star (we require at least 10 measurements from each star) and then averaging over the stars involved. This provides a more equal contribution from different latitudes covered and no star can dominate the average by its high number of measurements. We apply a median filter $(|x-\operatorname{median}(x)|>3 \times 1.4826 \times \operatorname{median}(\mid x-\operatorname{median}(x)) \mid)$ for the distribution of GOMOS values from any given star at each altitude. Any GOMOS outlier means that it and its paired WACCM data are removed. For ozone the number of outliers is less than $1 \%$ except at $0.01 \mathrm{hPa}$ (ozone minimum) and at the polar latitudes where the number of outliers can reach $5 \%$. For $\mathrm{NO}_{2}$ and $\mathrm{NO}_{3}$ the number of outliers is about $1 \%$ and up to $5 \%$ in the polar areas. All averages are calculated using the median estimator. After eliminating flagged data and applying minimum number limits we have 231923 ozone, $358738 \mathrm{NO}_{2}$ and $317653 \mathrm{NO}_{3}$ WACCM-GOMOS pairs in our comparisons (note that near the upper and lower altitude limits of the GOMOS retrievals the actual number of pairs is usually smaller). From the WACCM and GOMOS 5-day time series we calculate the WACCM-GOMOS mission average biases and the (Pearson) correlation coefficients $C(z)$. In this step we require that at least five time steps are included. This eliminates the latitude belt $80-90^{\circ} \mathrm{S}$ altogether. Notice that the time coverage of the polar latitudes is strongly restricted by the solar zenith condition (nighttime) applied on the GOMOS data. In the Antarctic $60-90^{\circ} \mathrm{S}$ the coverage is from mid-February to September and in the Arctic 60-90 $\mathrm{N}$ from mid-September to mid-April.

In addition to the general data collection rules already explained we paid special attention to the validity limits in altitude for GOMOS data. This work includes nighttime measurements from 138 stars and each of them have their own valid, constituent specific retrieval range. The GOMOS data we are using already include star specific valid altitude limits for all three gases focused on in this work. These limits are based on yearly averages. In order to handle rapidly changing events we need more dynamic determination of the validity ranges. Therefore, in this study we have calculated for 
each star, gas, latitudinal zone and time window (5-days) the average $t$-value profile (the median value divided by its uncertainty; see e.g. Eq. 1 in Kyrölä et al., 2010a). We reject those portions from the average profile that have $t<2$ (this also eliminates negative density averages even if negative individual values are accepted).

An average profile that passes the $t$-value criterion usually forms a continuous chain of density values (with $t>2$ ) in altitude and the rejected values (with $t<2$ ) are located at the low and high altitude parts of the profile. Sometimes two or more disconnected $t>2$ regions are also present. These regions may represent the real atmospheric state or they can be generated by noise. In the ozone minimum region around $0.01 \mathrm{hPa}(80 \mathrm{~km})$ density values are so small that the $t>2$ condition is not usually achieved but $t$ values recover again at higher altitudes. This minimum structure seems to be omnipresent and we will always include the minimum region in our ozone comparisons. In the polar regions large $\mathrm{NO}_{2}$ values above the normal validity range of $\mathrm{NO}_{2}$ are observed after a solar storm hit the Earth. This extension of the profile is short-lived and we apply a $t$ test to monitor its upper limit.

Disconnected noise generated $t>2$ regions are typically found at altitudes where the density of a retrieved gas approaches zero. When the density decreases the WACCM's distribution of density values (from an averaging domain) changes from an approximate normal distribution (natural variation) to a nearly lognormal type distribution because of the physical lower limit zero in the model. The GOMOS retrieval approach does not limit the retrieved gas values by a positivity condition as this could lead to bias. As the density approaches zero the GOMOS' distribution of density values remains nearly normal also covering negative values. Ideally this distribution would settle down around zero with $t \sim 0$ and with the width given by the noise in data. Unfortunately, sometimes this does not happen and we see the distribution average become positive with $t>2$. These "ghost" detections may, for example, be generated by the interference of the other gases retrieved at the same time. As a precautionary measure against these ghosts we reject altitudes where the GOMOS distribution (from a given star, region, time, altitude) includes more than $20 \%$ negative values. For polar latitudes we apply a more relaxed limit of $33 \%$, which allows our analysis to capture fast developing processes.

The procedures explained prevent GOMOS average densities from obtaining values too close to zero, whereas the corresponding WACCM averages are not constrained. For ozone the lowest values are obtained from the ozone minimum and they are about $0.05 \mathrm{ppm}$ for both WACCM and GOMOS. $\mathrm{NO}_{2}$ is removed from the lower Antarctic stratosphere during July-August before the Antarctic ozone hole. The lowest WACCM values (in the present work) are about $0.000015 \mathrm{ppb}$, whereas at the same altitudes the lowest GOMOS values are about $0.04 \mathrm{ppb}$. For $\mathrm{NO}_{3}$ at low altitudes WACCM shows $0.4 \mathrm{ppt}$, and GOMOS $1.7 \mathrm{ppt}$.

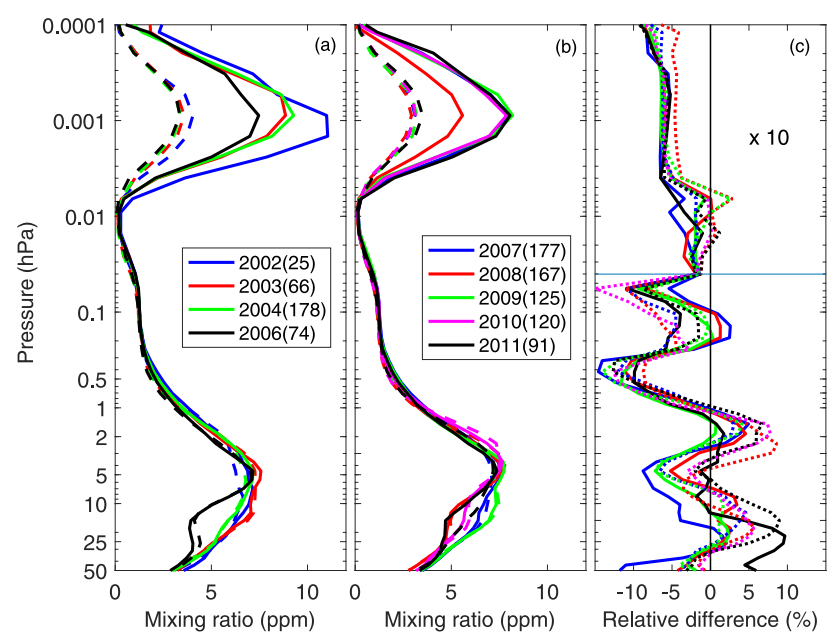

Figure 1. Ozone yearly median mixing ratio profiles and median relative differences from GOMOS Sirius occultations and from paired WACCM profiles from 2002 to 2011 in the $40-60^{\circ} \mathrm{S}$ latitude band. Occultations take place during late August to midSeptember. The vertical axis is pressure. (a, b) GOMOS profiles (solid lines) and WACCM profiles (dashed lines). The colour coding in the legend shows the measurement year and the number of measurements is in parentheses. (c) Relative median difference WACCM-GOMOS/median(GOMOS). Above $0.04 \mathrm{hPa}$ differences are divided by 10 . The colour coding for $(\mathbf{c})$ follows $(\mathbf{a}, \mathbf{b})$, but 2007-2011 lines are dotted.

\section{Ozone}

As an example of retrieved satellite ozone profiles and paired WACCM profiles, we show observations from the brightest star in the sky, Sirius in Fig. 1. It provides the best signal-tonoise ratio at all wavelengths of GOMOS stellar occultations. These measurements were taking place every year from late August to mid-September. In Fig. 1 we show the yearly median profiles from both the GOMOS observations and the WACCM simulation. It is evident that the observations and the model simulations generally agree well at all altitudes except in the neighbourhood of the second ozone peak (around $0.001 \mathrm{hPa}, 91 \mathrm{~km}$ ), where large differences and yearly variations are evident. The mission average 2002-2011 relative uncertainty of the GOMOS and WACCM Sirius profiles is better than $2 \%$ in the altitude range $0.05-50 \mathrm{hPa}$. The relative uncertainty grows to $10 \%$ at and around the ozone minimum at $0.01 \mathrm{hPa}$, but it again reaches $2 \%$ at the second peak and diverges at higher altitudes. The WACCM-GOMOS relative difference stays inside $\pm 10 \%$ between 0.05 and $50 \mathrm{hPa}$, but increases up to $60 \%$ at the second peak and grows still at higher altitudes. Differences are statistically sound in the mesosphere, whereas in the lower atmosphere the differences fluctuate on both sides of zero.

In order to get a more comprehensive view of WACCMGOMOS differences for all latitudes we now consider ozone profiles from all eligible GOMOS occulted stars. Profiles 


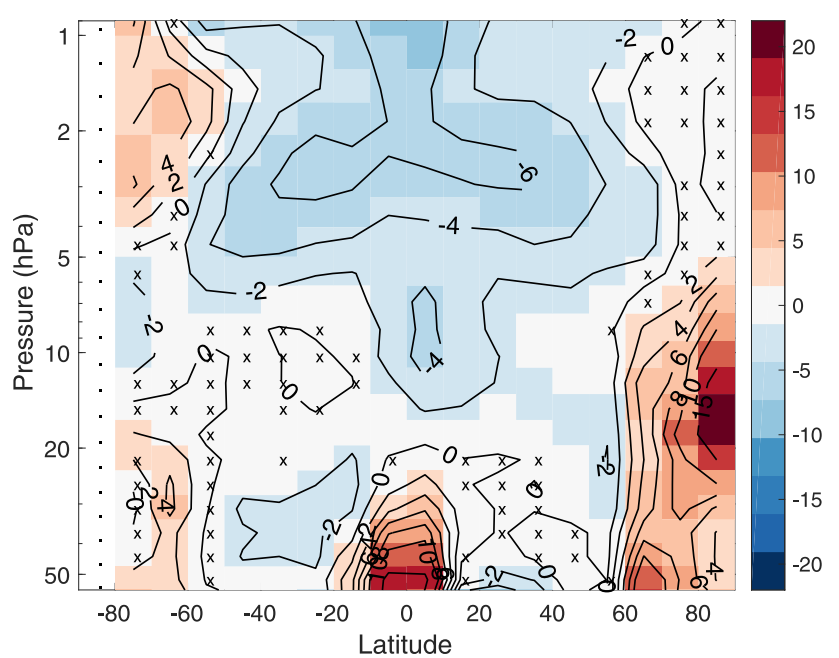

Figure 2. The median relative difference (WACCMGOMOS)/median(GOMOS) of the ozone mixing ratio (in \%) in the stratosphere over 2002-2011. Latitudes are from -90 to $+90^{\circ}$ with $10^{\circ}$ resolution. A crossed cell marks a point where the difference does not deviate from zero in a statistically significant way. A cell with a dot marks a point where there are no collocated profiles.

flagged by the ozone flags are not included, but all others are included for those pressure levels that pass the $t$ value and the distribution positivity criteria discussed in Sect. 4. Both WACCM and GOMOS main ozone maxima are at the Equator at $10.3 \mathrm{hPa}$. GOMOS maximum is $9.7 \mathrm{ppm}$ and WACCM $9.4 \mathrm{ppm}$ (difference $3 \%$ ). In the mesosphere-thermosphere the second mixing value maximum is at the Equator where the GOMOS mixing ratio is $10.5 \mathrm{ppm}$ at $0.0005 \mathrm{hPa}(94 \mathrm{~km})$ and WACCM $4 \mathrm{ppm}$ at $0.0009 \mathrm{hPa}(91 \mathrm{~km})$. The ozone minimum is located at $0.009-0.015 \mathrm{hPa}$ with minimum values above $0.1 \mathrm{ppm}$ (notice that WACCM's coarse pressure grid makes altitude estimates uncertain in the mesospherethermosphere). The altitude-latitude relative difference distribution between GOMOS and WACCM as a median average of 5-day time series from 2002 to 2011 is shown in Fig. 2 for the stratosphere and in Fig. 3 for the mesosphere-lower thermosphere. The validity range that applies to all latitudes is from 0.00012 to $85 \mathrm{hPa}$ (about $16-105 \mathrm{~km}$ ). The lower limit in Fig. 2 is taken as $52 \mathrm{hPa}$ (about $20 \mathrm{~km}$ ) in order to eliminate the GOMOS positive bias below $20 \mathrm{~km}$ in the tropics mentioned in Sect. 2. In both figures the differences are mostly statistically significant, points where the WACCMGOMOS difference is insignificant are marked by crosses.

In the stratosphere outside the polar latitudes WACCMGOMOS differences are generally small, WACCM values being $0-6 \%$ lower than GOMOS. This slightly exceeds the $\pm 3 \%$ uncertainty estimates of GOMOS ozone. Larger differences are seen in the tropical lower stratosphere and in the Arctic. In the tropics in the lower stratosphere we see that WACCM values are larger, up to $20 \%$, than GOMOS.

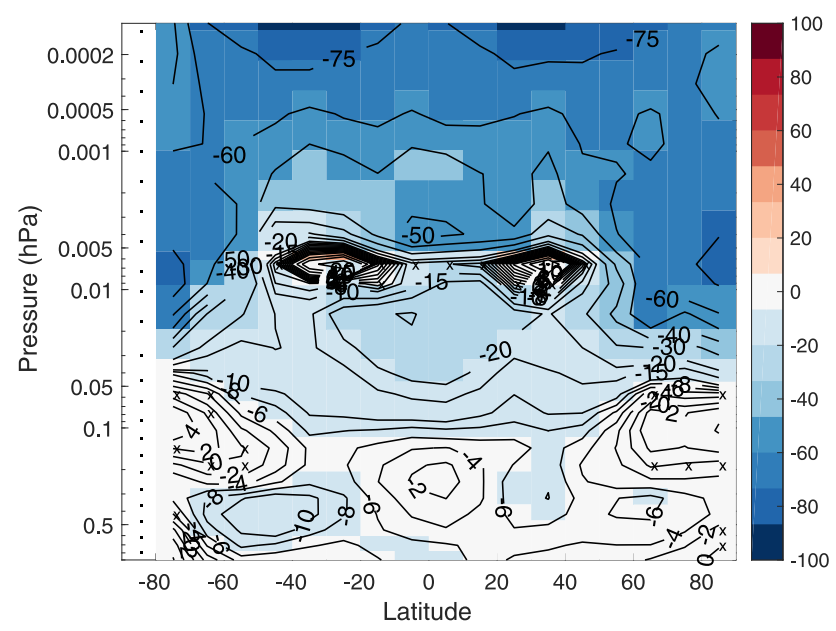

Figure 3. The median relative difference (WACCMGOMOS)/median(GOMOS) of the ozone mixing ratio (in \%) in the mesosphere over 2002-2011. Latitudes are from -90 to $+90^{\circ}$ with $10^{\circ}$ resolution. A crossed cell marks a point where the difference does not deviate from zero in a statistically significant way. A cell with a dot marks a point where there are no collocated profiles.

In the Arctic between 1 and $6 \mathrm{hPa}$ WACCM-GOMOS differences are small, between 6 and $50 \mathrm{hPa}$ WACCM is clearly larger than GOMOS, up to $20 \%$ difference at $15 \mathrm{hPa}$. In the Antarctic the differences are between -4 and $+6 \%$.

Figure 3 shows differences in the mesospheric-lower thermosphere, which are moderate up to $0.05 \mathrm{hPa}$ altitude or even up to $0.005 \mathrm{hPa}$ outside the polar latitudes. Around $0.1 \mathrm{hPa}$ in the polar areas WACCM and GOMOS agree within $\pm 5 \%$. During wintertime a so-called tertiary ozone peak appears in this region (see e.g. Marsh et al., 2001; Degenstein et al., 2005; Sofieva et al., 2009). In the upper mesosphere differences grow strongly and WACCM values are about $60 \%$ smaller than GOMOS around the second ozone peak. This result is in agreement with earlier comparisons (Tweedy et al., 2013; Smith et al., 2014), where WACCM was compared with MIPAS and SABER measurements. A similar modelmeasurement difference has been seen in a HAMMONIA model study (see Schmidt et al., 2006). The GOMOS retrieval is very straightforward in the mesosphere-lower thermosphere and we have not been able to identify any potential sources of uncertainty that could lead to such a large error in the GOMOS retrieval or data. Notice that GOMOS data uncertainty is large at the ozone minimum and the relative difference varies from positive to negative.

The 10 year mission averaged bias is, of course, a narrow measure of the compatibility of WACCM and GOMOS. We now investigate how WACCM and GOMOS ozone values develop in time. Figure 4 shows the correlation coefficient of WACCM and GOMOS from 5-day time series as a function of the altitude and latitude. In the stratosphere the correlation is very high, typically $0.85-0.95$. At altitudes between 


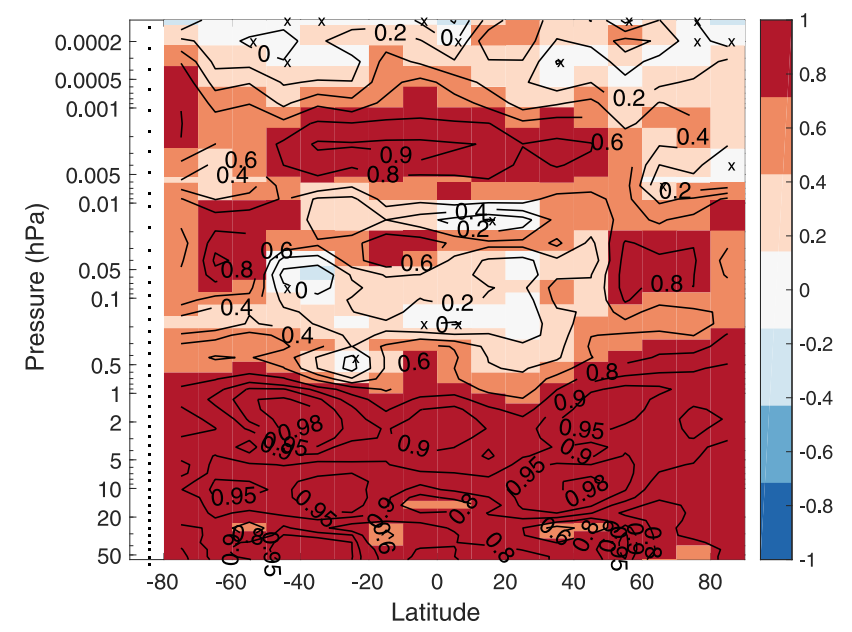

Figure 4. WACCM and GOMOS ozone mixing ratio correlation over 2002-2011. The correlation is calculated from 5-day time series. Latitudes are from -90 to $90^{\circ}$ with $10^{\circ}$ resolution. A crossed cell marks a point where the correlation does not deviate from zero in a statistically significant way. A cell with a dot marks a point where there are no collocated profiles.
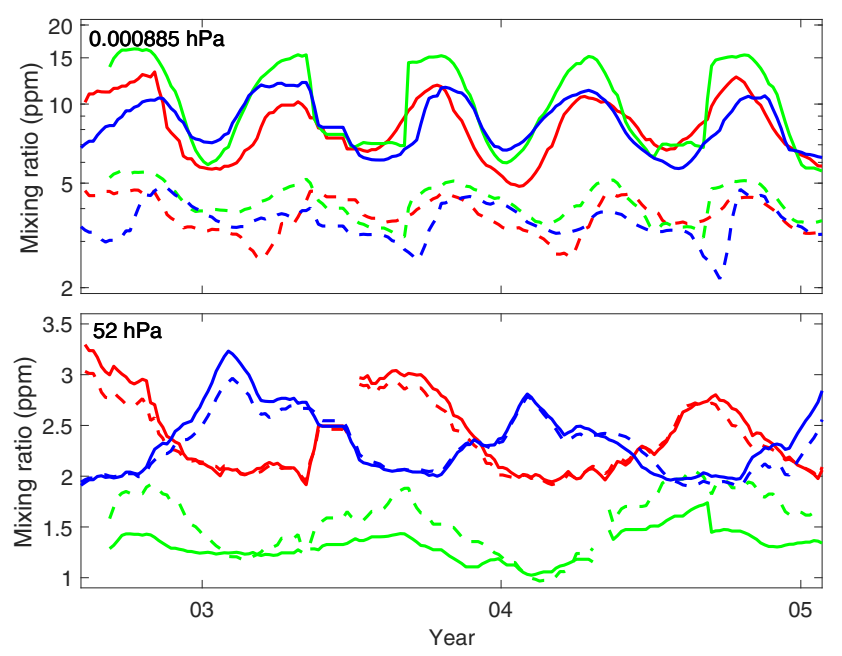

Figure 5. WACCM and GOMOS ozone 5-day time series $1 \mathrm{Au}-$ gust 2002-31 January 2005. Three latitude belts are shown: 50$30^{\circ} \mathrm{S}$ (red lines), $10^{\circ} \mathrm{S}-10^{\circ} \mathrm{N}$ (green) and $30-50^{\circ} \mathrm{N}$ (blue). GOMOS values are shown by solid lines, WACCM by dashed lines. The 5-day time series are smoothed by a moving average of 45 days. Note that in the top panel the $y$ axis is logarithmic.

the stratopause at $1 \mathrm{hPa}$ and the ozone minimum at $0.01 \mathrm{hPa}$ the correlation almost vanishes. High values are seen again between 0.01 and $0.001 \mathrm{hPa}$, but the final decrease starts just below the second ozone peak.

Figure 5 shows the comparison of the WACCM and GOMOS ozone mixing ratio 5-day time series from three latitude bands and at two pressure levels from August 2002 to January 2005 . The top panel shows the second maximum

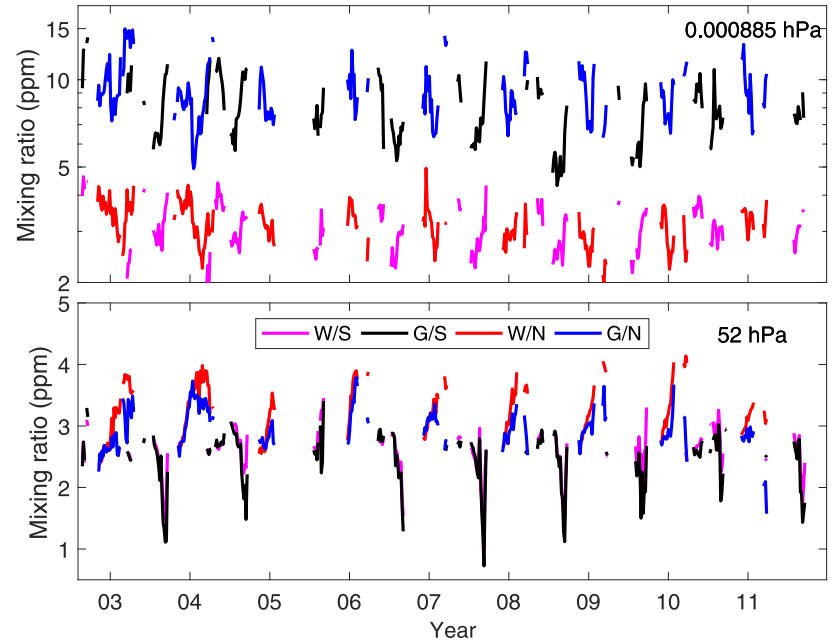

Figure 6. WACCM and GOMOS ozone mixing ratio 5-day time series from 2002 to 2011 in the Arctic $60-90^{\circ} \mathrm{N}$ and in the Antarctic $60-90^{\circ} \mathrm{S}$. In the top panel the $y$ axis is logarithmic. The colour coding symbols: W/S and W/N are WACCM in Antarctic, Arctic; $\mathrm{G} / \mathrm{S}$ and G/N are GOMOS in Antarctic, Arctic.
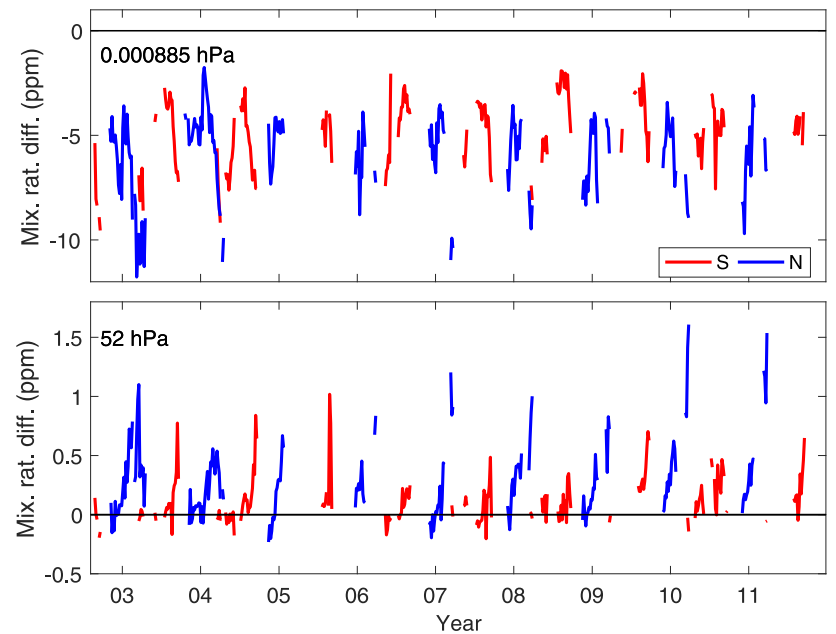

Figure 7. WACCM and GOMOS ozone mixing ratio difference from Fig. 6 in the Arctic $60-90^{\circ} \mathrm{N}$ and in the Antarctic $60-90^{\circ} \mathrm{S}$. The colour coding symbols: $\mathrm{S}$ is Antarctic and $\mathrm{N}$ is Arctic.

where a large bias between the WACCM and GOMOS is evident. Ozone in all three latitude bands shows semi-annual oscillations. WACCM and GOMOS correlation is highest 0.74 at the Equator, 0.54 at $50-30^{\circ} \mathrm{S}$ and 0.35 at $30-50^{\circ} \mathrm{N}$. At the lowest altitude in the bottom panel we can see that WACCM values in the tropics are consistently higher than GOMOS, resulting in the positive tropical bias in Fig. 2, whereas at the mid-latitudes there is a good agreement. Correlations are high, 0.83 at the Equator, 0.94 in the south and 0.95 in the north. 


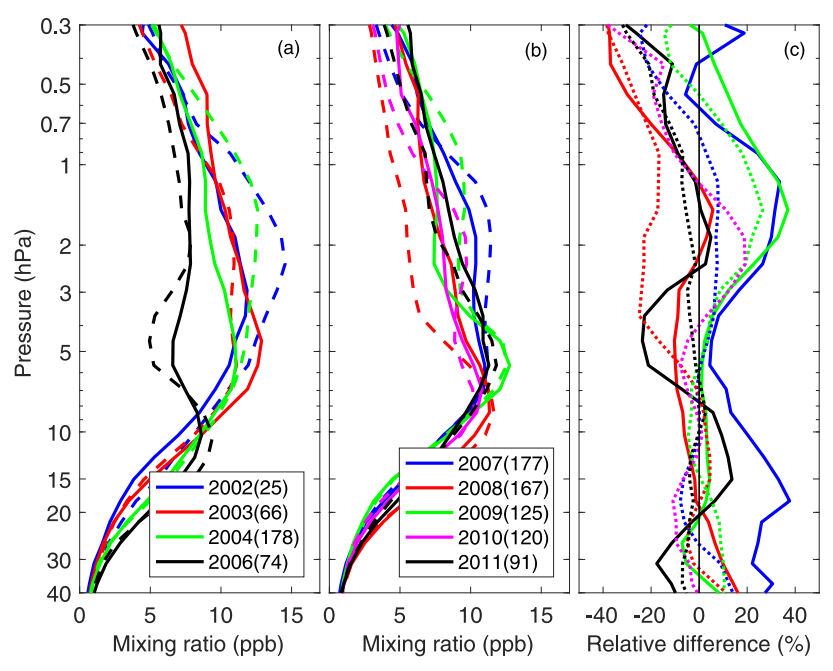

Figure 8. $\mathrm{NO}_{2}$ yearly median mixing ratio profiles and median relative differences from GOMOS Sirius occultations and from paired WACCM profiles from 2002 to 2011 in the $40-60^{\circ} \mathrm{S}$ latitude band. Occultations take place during late August to midSeptember. The vertical axis is pressure. $(\mathbf{a}, \mathbf{b})$ GOMOS profiles (solid lines) and WACCM profiles (dashed lines). The colour coding in the legend shows the measurement year and the number of measurements is in parentheses. (c) Relative median difference WACCM-GOMOS/median(GOMOS). The colour coding for (c) follows (a, b), but 2007-2011 lines are dotted.

In Fig. 6 we show the 5-day ozone mixing ratio time series in both polar regions at the same altitudes as in Fig. 5. The Arctic and Antarctic time series can be shown in the same plot because GOMOS nighttime coverage in these regions is almost complementary in time. Differences are shown in Fig. 7. The highest altitude in Fig. 6 (top panel) again shows the large differences of the second peak values (in both cases WACCM is on average $62 \%$ smaller than GOMOS). WACCM-GOMOS correlation is 0.59 in the Antarctic and only 0.35 in the Arctic. The bottom panel shows results at the lower end of the valid ozone range. The average WACCM-GOMOS difference is $2.8 \%$ in the Antarctic and $8.3 \%$ in the Arctic and correlations are 0.89 and 0.62 , respectively. In the Antarctic both WACCM and GOMOS show strong ozone reductions, but GOMOS reductions are generally larger. In the Arctic WACCM ozone values are, as a rule, considerably larger than GOMOS. This tendency continues to higher altitudes and "explains" the positive peak found in Fig. 2. The exceptionally large ozone loss in 2011 (see Manney et al., 2011) is clearly seen in GOMOS data, but not so clearly by WACCM. A similar even larger difference can be seen in 2010 but in this instance without a large reduction of ozone.

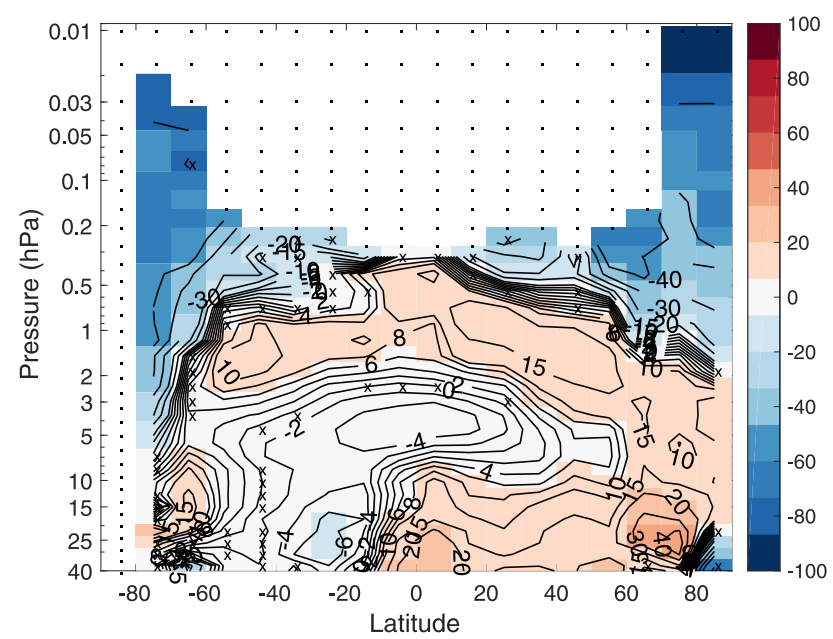

Figure 9. The median relative $\mathrm{NO}_{2}$ difference (WACCMGOMOS)/median(GOMOS) (in \%) over 2002-2011. Latitudes are from -90 to $90^{\circ}$ with $10^{\circ}$ resolution. A cross marks a point where the difference does not deviate from zero in a statistically significant way. A cell with a dot marks a point where there are no collocated profiles.

\section{Nitrogen dioxide}

In Fig. 8 we begin again with GOMOS profiles from the Sirius occultations in the $40-60^{\circ} \mathrm{S}$ latitude band. The average uncertainty of the WACCM and GOMOS median profiles is better than $5 \%$ at $40-0.5 \mathrm{hPa}$, whilst the relative WACCMGOMOS difference is $-10-+20 \%$ at the same altitude. Around the maximum $5 \mathrm{hPa}$ the difference is within $\pm 3 \%$. The yearly variation in profiles and differences is large. The reason for this variation is the location of Sirius occultations near the Antarctic vortex where sporadic $\mathrm{NO}_{2}$ enhancements are not totally contained in the polar region.

In Fig. 9 we show the median relative difference between WACCM and GOMOS as a function of latitude and altitude during 2002-2011. The most conspicuous feature of the figure is the variation of the upper valid altitude limit. In the polar regions GOMOS measurements reach up to near $0.05 \mathrm{hPa}$ (about $65 \mathrm{~km}$ ), whereas elsewhere the highest altitude is about $0.4 \mathrm{hPa}$ (about $55 \mathrm{~km}$ ). The all-latitude lower limit is $37 \mathrm{hPa}$ (about $21 \mathrm{~km}$ ). The variation of the upper validity limit is a consequence of data screening using $t$ values and the positivity condition of the distribution (see Sect. 4). It is important to keep in mind that the high altitude results from the polar regions come solely from the few short-lived $\mathrm{NO}_{2}$ enhancement events, whereas $\mathrm{NO}_{2}$ at the lower polar altitudes is measured by GOMOS during the whole winter season. In the polar areas at high altitudes WACCM values are smaller, by $50-90 \%$, than GOMOS. High GOMOS $\mathrm{NO}_{2}$ values are related to extraordinary events that will be discussed later. Outside the polar areas in the stratosphere WACCMGOMOS difference varies between -5 and $+25 \%$. Exclud- 


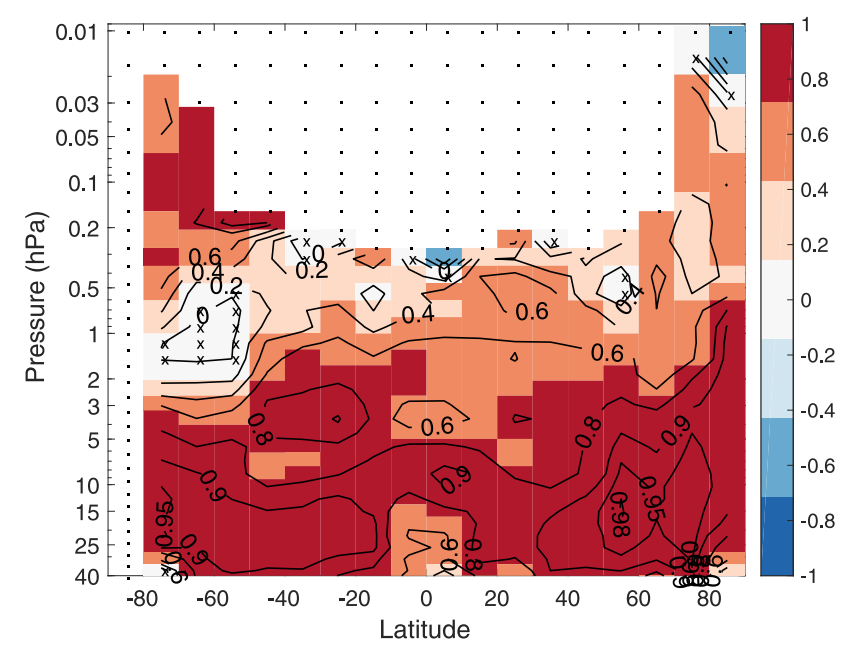

Figure 10. WACCM and GOMOS $\mathrm{NO}_{2}$ mixing ratio correlation over 2002-2011. Latitudes are from -90 to $90^{\circ}$ with $10^{\circ}$ resolution. A crossed cell marks a point where the correlation does not deviate from zero in a statistically significant way. A cell with a dot marks a point where there are no collocated profiles.

ing the polar regions however, the differences are inside the uncertainty estimates of GOMOS $\mathrm{NO}_{2}$. The mission average of the $\mathrm{NO}_{2}$ mixing ratio maximum is at $1.9 \mathrm{hPa}$ for WACCM and at $2.9 \mathrm{hPa}$ for GOMOS. Maximum values are both around $16 \mathrm{ppb}$ and situated at the Equator. The average values in the polar regions are still much higher: in the Arctic $86 \mathrm{ppb}$ and in the Antarctic $40 \mathrm{ppb}$, but these are only averages over the winter seasons.

In Fig. 10 we show the WACCM-GOMOS $\mathrm{NO}_{2}$ correlation coefficient's altitude-latitude distribution. In the stratosphere the correlation is high, 0.7-0.95, except in the upper stratosphere at the southern latitudes where the correlation vanishes. In the mesosphere at the polar latitudes the correlation varies between 0.3 and 0.9 .

Figure 11 shows WACCM and GOMOS $\mathrm{NO}_{2}$ time series at two pressure levels in the Arctic and Antarctic from 2002 to 2011. The differences are shown in Fig. 12. The upper panel in Fig. 11 shows that in both polar regions almost every winter high $\mathrm{NO}_{2}$ event is detected at an altitude much higher than the normal $\mathrm{NO}_{2}$ maximum. Most eminent peaks take place during the 2003 Antarctic winter and during the 20032004 Arctic winter. Elevated $\mathrm{NO}_{2}$ amounts, observed during the winter periods, are known to be generated by particle precipitation events (see e.g. Seppälä et al., 2004, 2007; Funke et al., 2011) and enhanced downward transport of $\mathrm{NO}_{x}$ from the lower thermosphere (e.g. Hauchecorne et al., 2007; Randall et al., 2009; Päivärinta et al., 2016; Funke et al., 2017). The lower pressure level (the bottom panel) shows the opposite tendency. The annual oscillation of $\mathrm{NO}_{2}$ has its minimum during the mid-winter. In the Antarctic WACCM NO acquires exceptionally low values (in this plot the minimum is $0.0017 \mathrm{ppb}$ ) due to denitrification of the lower stratosphere

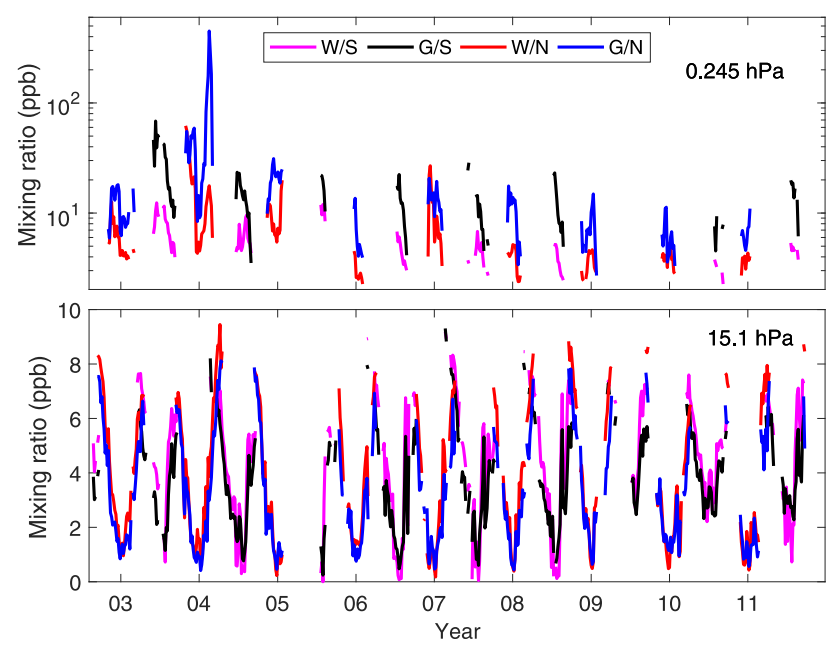

Figure 11. $\mathrm{NO}_{2}$ mixing ratio 5-day time series at two pressure levels from the Arctic $60-90^{\circ} \mathrm{N}$ and the Antarctic $60-90^{\circ} \mathrm{S}$. The colour coding symbols: W/S and W/N are WACCM in Antarctic Arctic; G/S and G/N are GOMOS in Antarctic, Arctic.

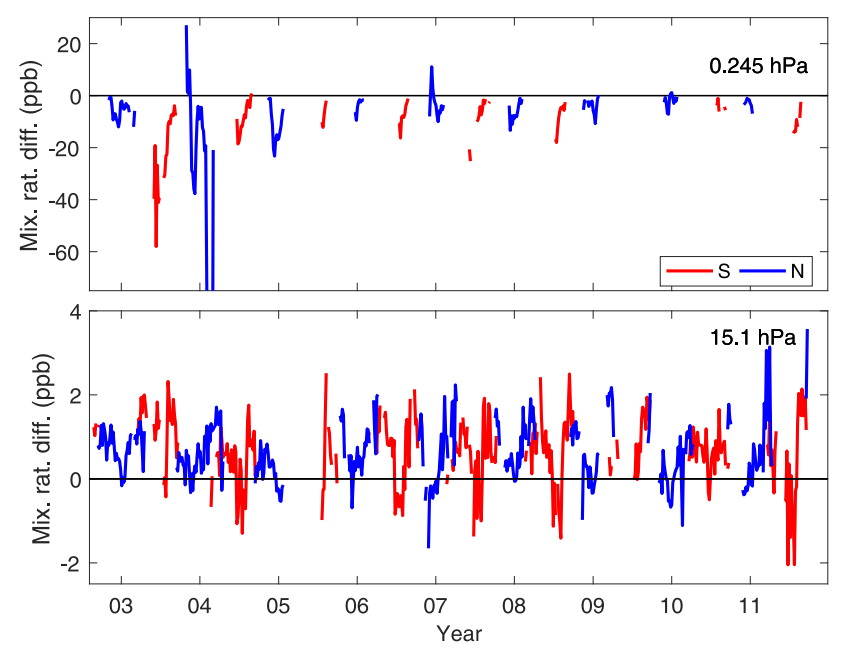

Figure 12. WACCM and GOMOS $\mathrm{NO}_{2}$ mixing ratio difference 5-day time series $2002-2011$ in the Arctic $60-90^{\circ} \mathrm{N}$ and in the Antarctic $60-90^{\circ} \mathrm{S}$. The colour coding symbols: $\mathrm{S}$ is Antarctic and $\mathrm{N}$ is Arctic.

(see e.g. Solomon, 1999). The corresponding GOMOS minimum value is much larger, $0.29 \mathrm{ppb}$, due to the positivity constraint imposed on GOMOS data.

During the 2003 Antarctic winter a strong increase in $\mathrm{NO}_{2}$ values started at the beginning of June and lasted until mid-September. This event has been meticulously studied in Funke et al. (2005) using satellite measurements from MIPAS/Envisat. The origin of the enhancement is the increase of the $\mathrm{NO}_{x}$ population in the thermosphere by electron precipitation and the subsequent downward transport by meridional transport. In GOMOS data the maximum 5-day median value $134 \mathrm{ppb}$ (at $0.07 \mathrm{hPa}$ ) is achieved during 15- 

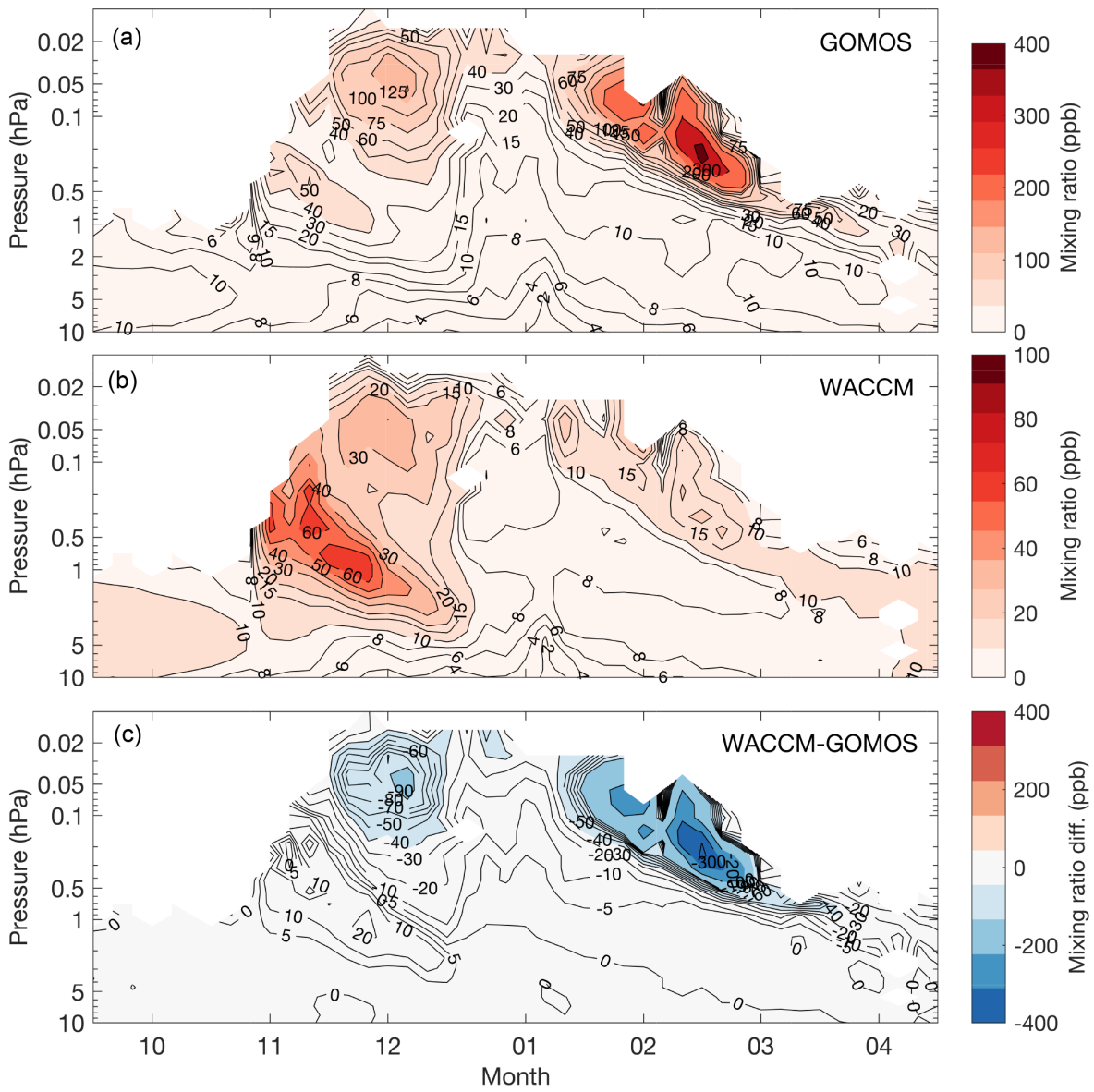

Figure 13. $\mathrm{NO}_{2}$ mixing ratio from 5-day time series during 15 September 2003 - 31 April 2004 from GOMOS (a), from WACCM (b) and WACCM-GOMOS difference (c) in the Arctic $60-90^{\circ} \mathrm{N}$. All in ppb units. Notice the difference in the colour scales.

19 July; the corresponding WACCM value is $24 \mathrm{ppb}$. The Antarctic $\mathrm{NO}_{2}$ enhancement during 2003 is important for two of our earlier results. In Fig. 8 we showed high yearly variation of Sirius $\mathrm{NO}_{2}$ profiles. WACCM 2002 and 2004 profiles around $2 \mathrm{hPa}$ are considerably larger than the corresponding GOMOS profiles, whereas during 2003 WACCM and GOMOS profiles agree. This agreement is due to the Antarctic $\mathrm{NO}_{2}$ enhancement during June-September 2003 that peaked before the Sirius measurements took place. This extra $\mathrm{NO}_{2}$ lifted GOMOS values until they were on par with WACCM. In Fig. 10 we showed how the WACCM-GOMOS correlation around $1 \mathrm{hPa}$ in the $50-80^{\circ} \mathrm{S}$ latitudinal range is much lower than elsewhere. This correlation (mission average) is dominated by the different temporal development of WACCM and GOMOS during June-August 2003 in this latitudinal region. Around $1 \mathrm{hPa}$ GOMOS values are dominated by the $\mathrm{NO}_{2}$ enhancement, whereas WACCM shows the usual annual cycle with the mid-winter minimum. Therefore, a strong anti-correlation emerges between WACCM and GOMOS during the peak of the enhancement event. This anticorrelation is repeated during most of the Antarctic winters, but with smaller amplitude. The correlation over all times averages to a vanishing correlation. During 2003 the $\mathrm{NO}_{2}$ enhancement and the WACCM-GOMOS anti-correlation extends to non-polar latitudes $50-60^{\circ} \mathrm{S}$.

Very strong $\mathrm{NO}_{2}$ increases in the Arctic took place between the end of October 2003 and the end of March 2004. This period covers strong proton events on 28-29 October and 2-3 November 2003 (the so-called "Halloween" event) and a strong descent period that started in mid-January 2004. The complexity of events is illustrated in Fig. 13 where we show WACCM and GOMOS $\mathrm{NO}_{2}$ mixing ratios and their difference as a function time and pressure. The peculiar ridge form of the distributions is a result from our dynamic GOMOS data selection. Before the Halloween there was not enough $\mathrm{NO}_{2}$ above $1 \mathrm{hPa}$ for GOMOS to retrieve it. During April this "normal" level is restored. The elevated $\mathrm{NO}_{2}$ amounts propagate with diminishing peak values down to $3.6 \mathrm{hPa}$ (about $35 \mathrm{~km}$ ).

It is evident that during the period shown, at altitudes above $5 \mathrm{hPa}$ GOMOS $\mathrm{NO}_{2}$ values are much larger than the those from WACCM most of the time. Figure 13 show how 


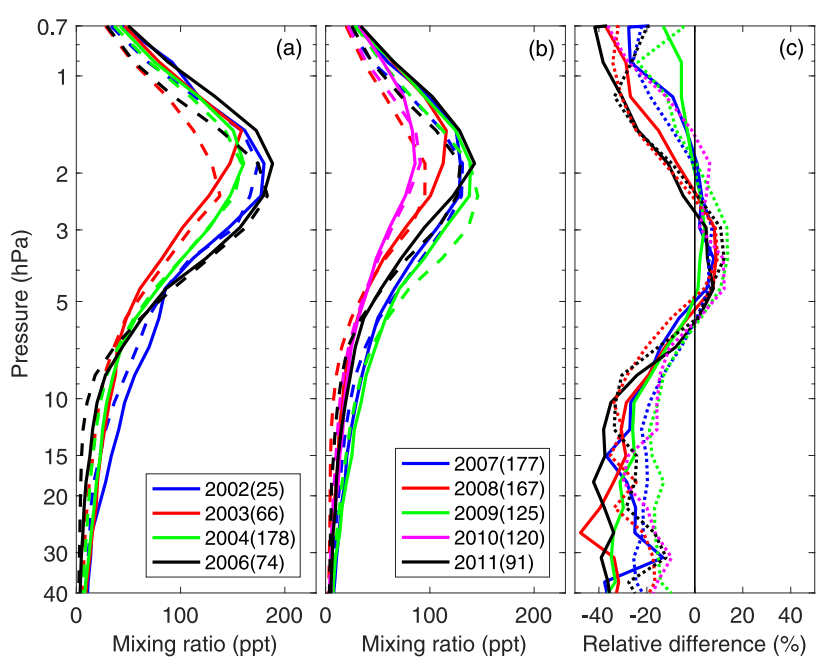

Figure 14. $\mathrm{NO}_{3}$ yearly median mixing ratio profiles and median relative differences from GOMOS Sirius occultations and from paired WACCM profiles from 2002 to 2011 in the latitude band $40-60^{\circ} \mathrm{S}$. Occultations take place during late August to midSeptember. The vertical axis is pressure. $(\mathbf{a}, \mathbf{b})$ GOMOS profiles (solid lines) and WACCM profiles (dashed lines). The colour coding in the legend shows the measurement year and the number of measurements is in parentheses. (c) Relative median difference WACCM-GOMOS/median(GOMOS). The colour coding for (c) follows (a, b), but 2007-2011 lines are dotted.

both WACCM and GOMOS capture the enhanced $\mathrm{NO}_{2}$ values around $0.5 \mathrm{hPa}$, produced by the SPEs at the end of October, and the descent until mid-December. WACCM seems to overestimate the magnitude of this enhancement by 5$20 \mathrm{ppb}$, which is in agreement with earlier results on $\mathrm{NO}_{y}$ (Funke et al., 2011, Fig. 15). The maximum difference is $39 \mathrm{ppb}$ on 30 October at a pressure level $0.19 \mathrm{hPa}$. WACCM reproduces only a fraction of the larger increase observed at $0.05 \mathrm{hPa}$ at the beginning of December. This is also true for the strong descent from the mesosphere to upper stratosphere observed in January-April. The maximum GOMOS value during these events is $450 \mathrm{ppb}$ at $0.245 \mathrm{hPa}$ as an average over 15-19 February 2004. The corresponding WACCM value is $18 \mathrm{ppb}$, meaning that the difference is $432 \mathrm{ppb}$. Mesospheric $\mathrm{NO}_{2}$, and $\mathrm{NO}_{x}$ in general, have been underestimated in WACCM during this period due to a combination of (1) incomplete representation of in situ production by EEP and (2) incomplete recovery from a sudden stratospheric warming in early January, resulting in insufficient descent (see Randall et al., 2015).

\section{$7 \quad$ Nitrogen trioxide}

In Fig. 14 we show $\mathrm{NO}_{3}$ profiles from the Sirius occultations in the $40-60^{\circ} \mathrm{S}$ latitude band. The relative uncertainty is better than $10 \%$ and the relative difference from -20 to $+5 \%$ in $1-40 \mathrm{hPa}$. Near the peak density $\sim 2 \mathrm{hPa}(40 \mathrm{~km}) \mathrm{WACCM}$

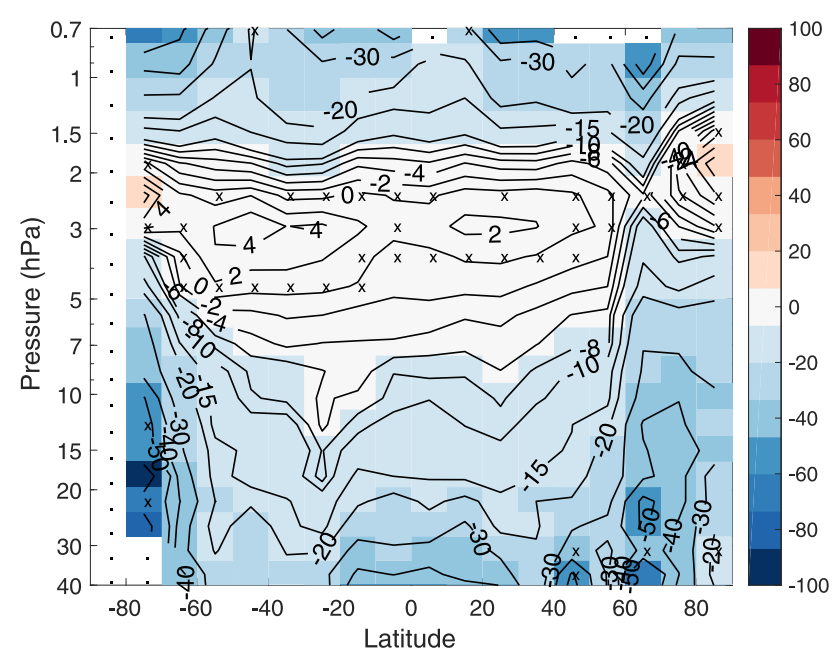

Figure 15. The relative $\mathrm{NO}_{3}$ difference (WACCMGOMOS)/median(GOMOS) (in \%) during 2002-2011. Latitudes are from -90 to $90^{\circ}$ with $10^{\circ}$ resolution. A cross marks a point where the difference does not deviate from zero in a statistically significant way. A cell with a dot marks a point where there are no collocated profiles.

and GOMOS values are within $\pm 2 \%$ but at lower altitudes WACCM values are consistently about $20 \%$ lower than GOMOS.

The mission averages shows that the general valid altitude region is from 0.7 to $37 \mathrm{hPa}$ (approximately $22-48 \mathrm{~km}$ ). In the polar regions $\mathrm{NO}_{3}$ values can be retrieved up to $0.3 \mathrm{hPa}$. GOMOS and WACCM NO 3 peaks at $2.35 \mathrm{hPa}$ with $270 \mathrm{ppt}$ and in the $40-50^{\circ} \mathrm{S}$ latitude band. The average $\mathrm{NO}_{3}$ values in the polar regions are below 160 ppt. In Fig. 15 we show the median relative differences from 2002 to 2011 between WACCM and GOMOS as a function of latitude and altitude. Around the peak of the $\mathrm{NO}_{3}$ profile the difference between WACCM and GOMOS is typically within $\pm 5 \%$. This is much better than uncertainty estimates of GOMOS $\mathrm{NO}_{3}$ from validation. In the polar regions, the maximum region excluded, WACCM NO 3 is up to $60 \%$ lower than GOMOS.

In Fig. 16 we show the WACCM-GOMOS $\mathrm{NO}_{3}$ correlation coefficient as a function of the altitude and latitude. Around the $\mathrm{NO}_{3}$ maximum all latitudes show very high correlations 0.95 . The reason for this high correlation is the fact that the mixing ratio of $\mathrm{NO}_{3}$ is very sensitive to temperature (see Hauchecorne et al., 2005; Marchand et al., 2007; Kyrölä et al., 2010a; Hakkarainen, 2013). When we calculate the correlation of WACCM's $\mathrm{NO}_{3}$ with the model temperature (in the stratosphere MERRA), we get values ranging from 0.7 to 0.99 in the altitude range $2-50 \mathrm{hPa}$. Similar positive correlation values are seen between GOMOS $\mathrm{NO}_{3}$ and MERRA temperature between 2 and $5 \mathrm{hPa}$. Temperature-related issues are a probable cause for the observed $\mathrm{NO}_{3}$ differences in the polar regions evident in Fig. 15. It is plausible that in these particular regions MERRA underestimates real temperatures 


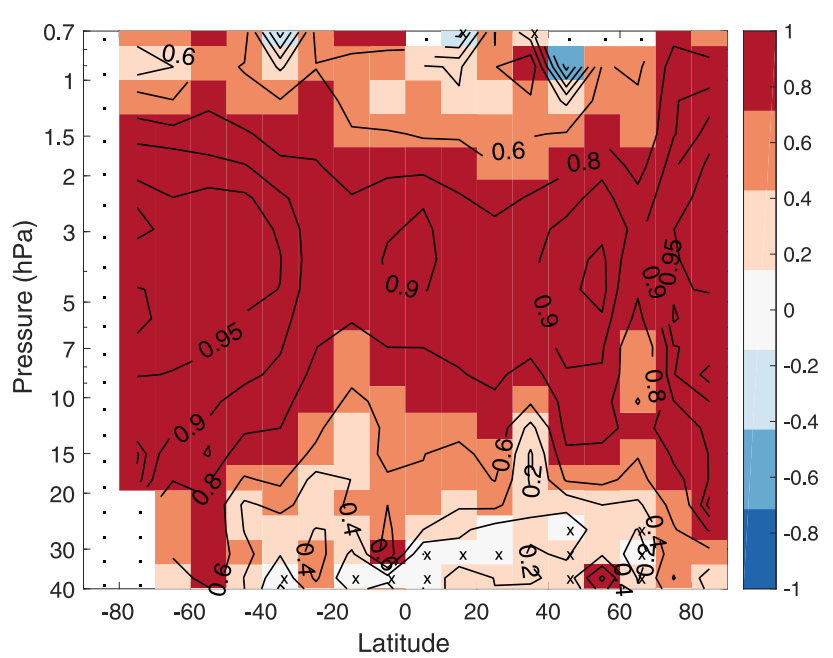

Figure 16. WACCM and GOMOS $\mathrm{NO}_{3}$ mixing ratio correlation for 2002-2011. Latitudes are from -90 to $90^{\circ}$ with $10^{\circ}$ resolution. A crossed cell marks a point where the correlation does not deviate from zero in a statistically significant way. A cell with a dot marks a point where there are no collocated profiles.

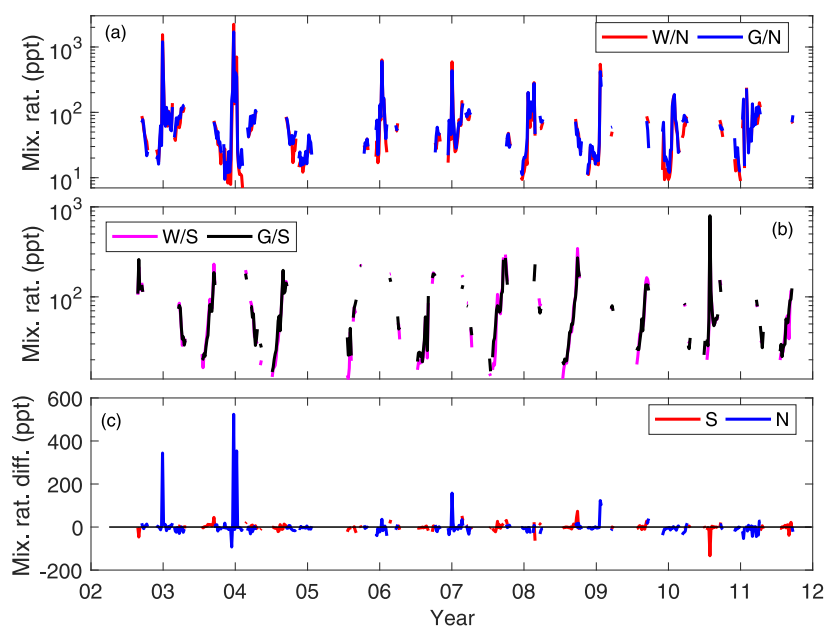

Figure 17. $\mathrm{NO}_{3}$ mixing ratio 5-day time series at $3.7 \mathrm{hPa}$ from WACCM and GOMOS from 2002 to 2011 in the Arctic 60$90^{\circ} \mathrm{N}$ (a) and in the Antarctic $60-90^{\circ} \mathrm{S}$ (b). The colour coding symbols: W/S and W/N are WACCM in Antarctic, Arctic; G/S and G/N are GOMOS in Antarctic, Arctic. In the both panels the $y$ axis is logarithmic. In (c) the mixing ratio difference is shown for the Arctic and the Antarctic in the mixing ratio unit. The colour coding symbols: $\mathrm{S}$ is Antarctic, $\mathrm{N}$ is Arctic.

except in the neighbourhood of the $\mathrm{NO}_{3}$ maximum. The temporal cycle is correct but the absolute values differ.

Dramatic examples of the temperature dependence of $\mathrm{NO}_{3}$ can be seen in the polar time series of Fig. 17 at $3.7 \mathrm{hPa}$ (this altitude seems to be most sensitive to temperature). In the Arctic, the strongest peaks in mixing ratio are caused by the large changes in temperature during SSW events (e.g. Sofieva
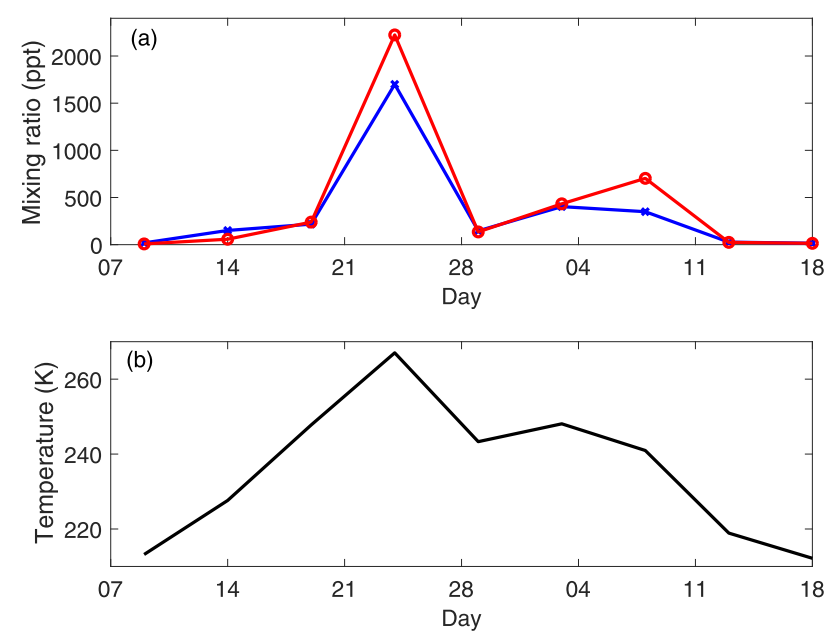

Figure 18. (a) WACCM (red) and GOMOS (blue) $\mathrm{NO}_{3}$ 5-day time series 7 December 2003-18 January 2004 in the Arctic $60-90^{\circ} \mathrm{N}$ at $3.7 \mathrm{hPa}$. (b) MERRA temperature for the same period and altitude.

et al., 2012; Butler et al., 2017). In the Antarctic the $\mathrm{NO}_{3}$ cycle during the study period follows the normal annual cycle of the temperature with one exception: during the 5-day period around 28 July $2010 \mathrm{NO}_{3}$ values show a major jump (for analysis of this case, see de Laat and van Weele, 2011). Note that the famous 2002 SSW in Antarctica was not captured by GOMOS measurements. It seems that at the sudden warmings (with the Antarctic case excluded) WACCM values considerably exceed the corresponding GOMOS values and we can speculate that MERRA overestimates the real temperature. A detailed evolution of the strong Arctic event in December 2003-January 2004 is shown in Fig. 18. WACCM and GOMOS values show similar temporal development, but the actual values differ.

In order to further study the temperature dependence of $\mathrm{NO}_{3}$, we have plotted WACCM and GOMOS mixing ratio values as a function of MERRA temperature at $3.7 \mathrm{hPa}$ in Fig. 19. The dependence on temperature is nearly exponential from both sources in the polar regions. The coefficients of the exponential are 0.069 1/K for the Antarctic and 0.079 $1 / \mathrm{K}$ for the Arctic. The fitting of the equatorial values is more prone to errors as the temperature variation is more limited than in the polar regions. The two polar coefficients decrease below and above the selected altitude level $3.7 \mathrm{hPa}$.

In Brasseur and Solomon (2005) and Marchand et al. (2004) a formula for the ratio of $\mathrm{NO}_{3}$ to $\mathrm{O}_{3}$ densities is derived assuming nighttime chemical equilibrium. In Fig. 20 we show how this theoretical ratio and the ratio calculated from the WACCM simulated data compare with the ratio determined from GOMOS data. The theory values are calculated using temperature from WACCM. WACCM, GOMOS and the theoretical values show good agreement inside the maximum region of the $\mathrm{NO}_{3}$ mixing ratio excluding polar latitudes. Theoretical values start strongly increasing com- 


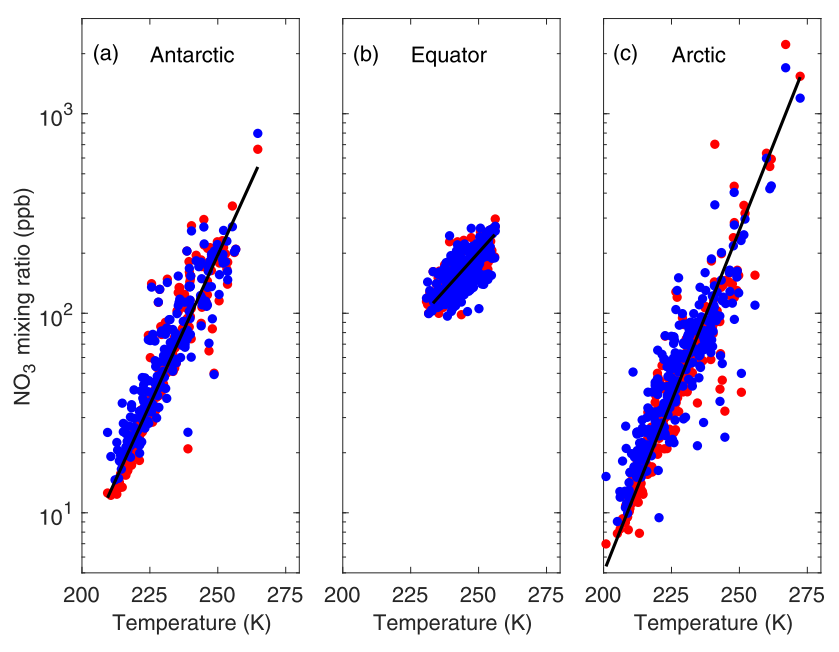

Figure 19. $\mathrm{NO}_{3}$-temperature scatter plot at $3.7 \mathrm{hPa}$. (a) The Antarctic $60-90^{\circ} \mathrm{S}$. (b) The Equator $10^{\circ} \mathrm{S}-10^{\circ} \mathrm{N}$. (c) The Arctic 60$90^{\circ} \mathrm{N}$. Red dots are from WACCM and blue dots from GOMOS. Exponential fits are applied to temperature gridded WACCM data. Data for all latitudes are from 5-day time series from 2002 to 2011.

pared to GOMOS above $1.5 \mathrm{hPa}$, whereas WACCM slightly decrease in the same region. Both WACCM and theoretical values are lower with respect to GOMOS below $10 \mathrm{hPa}$.

\section{Conclusions}

In this work we compared the state-of-the-art chemistryclimate model WACCM to measurements from the satellite instrument GOMOS. Measurements cover years from 2002 to 2011 and were made at nighttime. We compared $\mathrm{O}_{3}, \mathrm{NO}_{2}$ and $\mathrm{NO}_{3}$ mixing ratios using 5-day time series. We also calculated the correlation of GOMOS and WACCM time series. The comparisons are done with collocated profiles, which eliminate differences from natural variability and sampling patterns.

This comparison required considerable effort to ensure the quality of the observational data. GOMOS nighttime observations collect photons from 138 different stars which vary widely in their luminosity and effective temperature. This variation causes large differences in the quality of trace gas profiles. For ozone we used three GOMOS ozone data flags to remove low-quality profiles, for $\mathrm{NO}_{2}$ and $\mathrm{NO}_{3}$ there are no such quality flags available. In order to form reliable average profiles from individual GOMOS trace gas profiles it was necessary to determine the altitude limits of valid data in profiles. In the present work we determined the limits for all time steps, all latitude bands and for all stars using two criteria. First, we demanded that for valid altitudes the $t$ value (average density/uncertainty) was larger than 2. Second, we demanded that the distribution of GOMOS values was located mainly on positive density values. This approach has

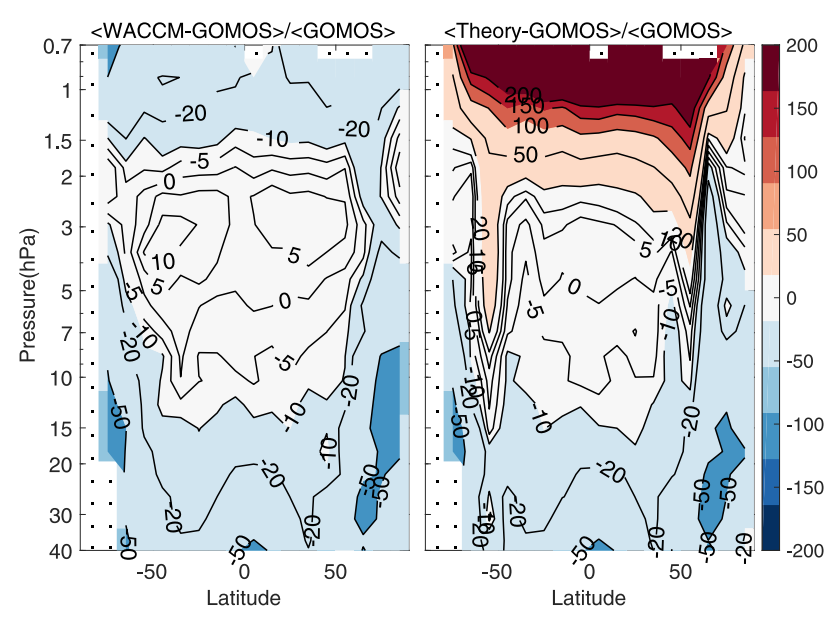

Figure 20. The $\mathrm{NO}_{3} / \mathrm{O}_{3}$ ratio from WACCM and from the equilibrium chemistry theory (see Brasseur and Solomon, 2005) compared to the corresponding ratio from GOMOS. Relative differences. Data are from 5-day time series from 2002 to 2011. A cell with a dot marks a point where there are no collocated profiles.

produced altitude limits of valid data that were previously estimated using a priori knowledge.

Our comparisons show that in the stratosphere $(1-50 \mathrm{hPa})$ outside the polar regions WACCM ozone values are 0-6\% smaller than GOMOS values, which slightly exceeds the uncertainty estimates of GOMOS measurements. The difference patterns are consistent in time during 2002-2011. In the tropical region in the lower stratosphere WACCM measurements show consistently larger values (up to $20 \%$ ) than GOMOS. In the Arctic WACCM is also larger (up to $20 \%$ ) than GOMOS. In the Antarctic the ozone hole evolution is in better agreement. In the mesosphere above the ozone minimum at $0.01 \mathrm{hPa}$ (or $80 \mathrm{~km}$ ) large differences are found between WACCM and GOMOS. Differences exist in the values of the mixing ratio and also in the correlation of time series at the second ozone maximum. Differences may be connected to WACCM's temperatures in the mesosphere or to specific parameter values that control the gravity wave dissipation in WACCM (see Smith et al., 2014). The correlation of GOMOS and WACCM time series is high except in the nonpolar region in the mesosphere just below the ozone minimum and at the altitudes from the second ozone maximum and above.

Outside the polar areas and in the validity region 0.4 $37 \mathrm{hPa}$ WACCM and GOMOS $\mathrm{NO}_{2}$ values agree reasonably well. In the polar areas, where solar particle precipitation and downward transport from the thermosphere enhance $\mathrm{NO}_{2}$ abundances, GOMOS values are much larger than WACCM. The correlation of time series is moderate in the stratosphere except in the upper stratosphere at southern latitudes where $\mathrm{NO}_{2}$ downdraft events cause anti-correlation between WACCM and GOMOS. GOMOS measurements and simulation by the new version of WACCM are in better agree- 


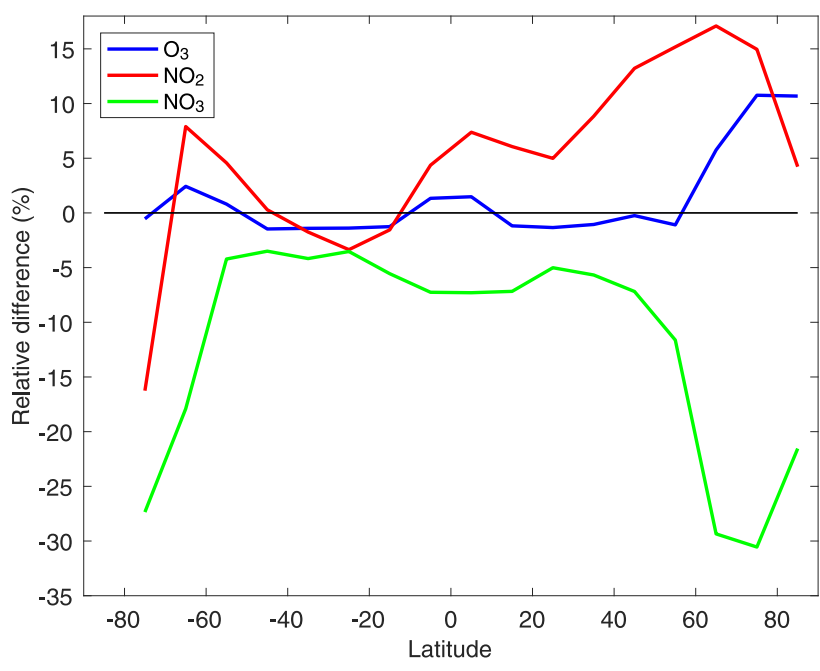

Figure 21. The relative difference of WACCM and GOMOS vertical columns of ozone, $\mathrm{NO}_{2}$ and $\mathrm{NO}_{3}$. The vertical extent of the column is $0.0002-50 \mathrm{hPa}$ for ozone, $0.4-37 \mathrm{hPa}$ for $\mathrm{NO}_{2}$ and 1.1$26 \mathrm{hPa}$ for $\mathrm{NO}_{3}$.

ment for the direct particle initiated $\mathrm{NO}_{2}$ increases, but for the downdraft cases GOMOS values are much larger than those from WACCM. The overall correlation of the polar 5day time series is still quite high in the middle atmosphere.

For $\mathrm{NO}_{3}$, we find that WACCM values largely agree with GOMOS. In the validity region $1.2-5 \mathrm{hPa}$ the correlation is very high. Because the $\mathrm{NO}_{3}$ abundance is controlled by temperature, the WACCM-GOMOS $\mathrm{NO}_{3}$ difference can be used as an indicator of the accuracy of MERRA temperature information. We found that $\mathrm{NO}_{3}$ temperature dependence can be fitted reasonably well by an exponential function in the polar regions. The $\mathrm{NO}_{3} / \mathrm{O}_{3}$ ratio agrees with the equilibrium chemical theory quite accurately.

The differences in trace gas profiles can also be studied by comparing vertical column densities. The vertical columns can be calculated from number densities at geometric heights of the pressure levels. In Fig. 21 we show the relative difference of WACCM and GOMOS columns. The vertical extent of the column is $0.0002-50 \mathrm{hPa}$ for ozone, $0.4-37 \mathrm{hPa}$ for $\mathrm{NO}_{2}$ and $1.1-26 \mathrm{hPa}$ for $\mathrm{NO}_{3}$. These limits avoid all missing data cases and include the number density maxima of the gases. The vertical ozone column is 208 Dobson units at the Equator (the full vertical column is about 300 Dobson units) and about 145 Dobson units at the poles. The total column for $\mathrm{NO}_{2}$ varies between 0.05 and 0.17 Dobson units and between 0.0003 and 0.001 Dobson units for $\mathrm{NO}_{3}$. We can see that GOMOS and WACCM total ozone columns agree within $\pm 2 \%$ except in the Arctic where the WACCM column is $10 \%$ larger than GOMOS. WACCM NO 2 column is up to $15 \%$ larger than GOMOS except at the southernmost latitudes where enhanced $\mathrm{NO}_{2}$ events have deeper penetration than in north. WACCM NO 3 columns are $-5 \%$ smaller outside the polar areas, whereas in the polar areas the difference is around $30 \%$.

In this work we have attempted to expose agreements and differences between the WACCM model and the GOMOS measurements. To understand underlying reasons for differences a detailed and presumably difficult analysis of the model physics and chemistry is necessary. Perhaps the only exception is temperature from the external meteorological model that we think is the reason for $\mathrm{NO}_{3}$ differences in the polar regions. On the GOMOS data side, there is still room for better algorithms and more extensive validation especially in the polar regions. A wider comparison including additional relevant constituents from other satellite instruments would help to vindicate our results and to pinpoint the underlying reasons for differences.

Data availability. All data can be requested form the first author of this paper (see correspondence information). Data will be placed on a publicly accessible server in due time. The size of the GOMOSpaired WACCM data set is $2.2 \mathrm{~Gb}$. The GOMOS data used in this work is a MATLAB version of the so-called user friendly (UFP) GOMOS data. These UFP data (in netCDF-4 format) are available from the ESA data portal (ESA, 2018). The collocated MATLAB data sets include WACCM-data and the paired satellite data and is $4.8 \mathrm{~Gb}$.

Code availability. The SD-WACCM-D model will be available from NCAR. All the WACCM and satellite data have been processed using MATLAB software. The specific routines used in this work can be requested from the first author.

Competing interests. The authors declare that they have no conflict of interest.

Special issue statement. This article is part of the special issue "Quadrennial Ozone Symposium 2016 - Status and trends of atmospheric ozone (ACP/AMT inter-journal SI)". It is a result of the Quadrennial Ozone Symposium 2016, Edinburgh, United Kingdom, 4-9 September 2016.

Acknowledgements. The authors want to thank anonymous reviewers for useful comments and corrections. The work of Erkki Kyrölä was partly supported by ESA's ALGOM project. The work of Monika E. Andersson and Pekka T. Verronen was supported by the Academy of Finland through the project no. 276926 (SECTIC: Sun-Earth Connection Through Ion Chemistry). Daniel R. Marsh was supported in part by NASA grant NNX12AD04G. The National Center for Atmospheric Research is operated by the University Corporation for Atmospheric Research under sponsorship of the National Science Foundation. 
Edited by: Stefan Reis

Reviewed by: two anonymous referees

\section{References}

Andersson, M. E., Verronen, P. T., Marsh, D. R., Päivärinta, S.-M., and Plane, J. M. C.: WACCM-D - Improved modeling of nitric acid and active chlorine during energetic particle precipitation, J. Geophys. Res.-Atmos., 121, 10328-10341, https://doi.org/10.1002/2015JD024173, 2016.

Andersson, M. E., Verronen, P. T., Marsh, D. R., Seppälä, A., Päivärinta, S.-M., Rodger, C. J., Clilverd, M. A., Kalakoski, N., and van de Kamp, M.: Polar Ozone Response to Energetic Particle Precipitation Over Decadal Time Scales: The Role of Medium-Energy Electrons, J. Geophys. Res.-Atmos., 123, 607622, https://doi.org/10.1002/2017JD027605, 2018.

Bertaux, J. L., Kyrölä, E., Fussen, D., Hauchecorne, A., Dalaudier, F., Sofieva, V., Tamminen, J., Vanhellemont, F., Fanton D'Andon, O., Barrot, G., Mangin, A., Blanot, L., Lebrun, J. C., Pérot, K., Fehr, T., Saavedra, L., Leppelmeier, G. W., and Fraisse, R.: Global ozone monitoring by occultation of stars: an overview of GOMOS measurements on ENVISAT, Atmos. Chem. Phys., 10, 12091-12148, https://doi.org/10.5194/acp-10-12091-2010, 2010.

Brasseur, G. P. and Solomon, S.: Aeronomy of the Middle Atmosphere, in: 3rd revised and enlarged Edn., Springer, Dordrecht, 2005.

Butler, A. H., Sjoberg, J. P., Seidel, D. J., and Rosenlof, K. H.: A sudden stratospheric warming compendium, Earth Syst. Sci. Data, 9, 63-76, https://doi.org/10.5194/essd-9-63-2017, 2017.

Ceccherini, S., Cortesi, U., Verronen, P. T., and Kyrölä, E.: Technical Note: Continuity of MIPAS-ENVISAT operational ozone data quality from full- to reduced-spectralresolution operation mode, Atmos. Chem. Phys., 8, 2201-2212, https://doi.org/10.5194/acp-8-2201-2008, 2008.

Chandran, A. and Collins, R. L.: Stratospheric sudden warming effects on winds and temperature in the middle atmosphere at middle and low latitudes: a study using WACCM, Ann. Geophys., 32, 859-874, https://doi.org/10.5194/angeo-32-859-2014, 2014.

Degenstein, D. A., Gattinger, R. L., Lloyd, N. D., Bourassa, A. E., Wiensz, J. T., and Llewellyn, E. J.: Observations of an extended mesospheric tertiary ozone peak, J. Atmos. Sol.-Terr. Phy., 67, 1395-1402, https://doi.org/10.1016/j.jastp.2005.06.019, 2005.

de Laat, A. T. J. and van Weele, M.: The 2010 Antarctic ozone hole: Observed reduction in ozone destruction by minor sudden stratospheric warmings, Scient. Rep., 1, 38, https://doi.org/10.1038/srep00038, 2011.

ESA: Envisat-GOMOS, An instrument for global atmospheric ozone monitoring, in: vol. SP-1244, European Space Agency, Noordwijk, the Netherlands, 2001.

ESA: UFP data (in netCDF-4 format), https://earth.esa.int/ web/guest/data-access/browse-data-products, last access: 10 April 2018.

Eyring, V., Shepherd, T., and Waugh, D.: SPARC CCMVal Report on the Evaluation of Chemistry-Climate Models, in: Vol. 5, SPARC Office, http://www.sparc-climate.org/ publications/sparc-reports/, (last access: 10 April 2018), 2010.
Eyring, V., Arblaster, J. M., Cionni, I., Sedláček, J., Perlwitz, J., Young, P. J., Bekki, S., Bergmann, D., Cameron-Smith, P., Collins, W. J., Faluvegi, G., Gottschaldt, K. D., Horowitz, L. W., Kinnison, D. E., Lamarque, J. F., Marsh, D. R., Saint-Martin, D., Shindell, D. T., Sudo, K., Szopa, S., and Watanabe, S.: Longterm ozone changes and associated climate impacts in CMIP5 simulations, J. Geophys. Res.-Atmos., 118, 5029-5060, 2013.

Funke, B., López-Puertas, M., Gil-Lopez, S., von Clarmann, T., Stiller, G. P., Fischer, H., and Kellmann, S.: Downward transport of upper atmospheric $\mathrm{NO}_{x}$ into the polar stratosphere and lower mesosphere during the Antarctic 2003 and Arctic 2002/2003 winters, J. Geophys. Res., 110, D24308, https://doi.org/10.1029/2005JD006463, 2005.

Funke, B., Baumgaertner, A., Calisto, M., Egorova, T., Jackman, C. H., Kieser, J., Krivolutsky, A., López-Puertas, M., Marsh, D. R., Reddmann, T., Rozanov, E., Salmi, S.-M., Sinnhuber, M., Stiller, G. P., Verronen, P. T., Versick, S., von Clarmann, T., Vyushkova, T. Y., Wieters, N., and Wissing, J. M.: Composition changes after the "Halloween" solar proton event: the High-Energy Particle Precipitation in the Atmosphere (HEPPA) model versus MIPAS data intercomparison study, Atmos. Chem. Phys., 11, 90899139, https://doi.org/10.5194/acp-11-9089-2011, 2011.

Funke, B., Ball, W., Bender, S., Gardini, A., Harvey, V. L., Lambert, A., López-Puertas, M., Marsh, D. R., Meraner, K., Nieder, H., Päivärinta, S.-M., Pérot, K., Randall, C. E., Reddmann, T., Rozanov, E., Schmidt, H., Seppälä, A., Sinnhuber, M., Sukhodolov, T., Stiller, G. P., Tsvetkova, N. D., Verronen, P. T., Versick, S., von Clarmann, T., Walker, K. A., and Yushkov, V.: HEPPA-II model-measurement intercomparison project: EPP indirect effects during the dynamically perturbed NH winter 2008-2009, Atmos. Chem. Phys., 17, 35733604, https://doi.org/10.5194/acp-17-3573-2017, 2017.

Garcia, R. R., Marsh, D. R., Kinnison, D. E., Boville, B. A., and Sassi, F.: Simulation of secular trends in the middle atmosphere, 1950-2003, J. Geophys. Res.-Atmos., 112, D09301, https://doi.org/10.1029/2006JD007485, 2007.

Hakkarainen, J.: On state and parameter estimation in chaotic systems, PhD thesis, Lappeenranta University of Technology, http://urn.fi/URN:ISBN:978-952-265-500-4 (last access: 10 April 2018), 2013.

Hakkarainen, J., Tamminen, J., Moore, J. R., and Kyrölä, E.: Direct comparisons of GOMOS and SAGE III $\mathrm{NO}_{3}$ vertical profiles, Atmos. Meas. Tech., 5, 1841-1846, https://doi.org/10.5194/amt5-1841-2012, 2012.

Hauchecorne, A., Bertaux, J.-L., Dalaudier, F., Cot, C., Lebrun, J.C., Bekki, S., Marchand, M., Kyrölä, E., Tamminen, J., Sofieva, V., Fussen, D., Vanhellemont, F., Fanton d'Andon, O., Barrot, G., Mangin, A., Théodore, B., Guirlet, M., Snoeij, P., Koopman, R., Saavedra de Miguel, L., Fraisse, R., and Renard, J.-B.: First simultaneous global measurements of nighttime stratospheric $\mathrm{NO}_{2}$ and $\mathrm{NO}_{3}$ observed by Global Ozone Monitoring by Occultation of Stars (GOMOS)/Envisat in 2003, J. Geophys. Res., 110, D18301, https://doi.org/10.1029/2004JD005711, 2005.

Hauchecorne, A., Bertaux, J.-L., Dalaudier, F., Russell, J. M., Mlynczak, M. G., Kyrölä, E., and Fussen, D.: Large increase of $\mathrm{NO}_{2}$ in the north polar mesosphere in JanuaryFebruary 2004: Evidence of a dynamical origin from GOMOS/ENVISAT and SABER/TIMED data, Geophys. Res. Lett., 34, L03810, https://doi.org/10.1029/2006GL027628, 2007. 
Hedin, A. E.: Extension of the MSIS thermospheric model into the middle and lower atmosphere, J. Geophys. Res., 96, 1159-1172, 1991.

Hegglin, M. I. and Tegtmeier, S. (Eds.): The SPARC Data Initiative: Assessment of stratospheric trace gas and aerosol climatologies from satellite limb sounders, in: Vol. 8, SPARC Office, http://www.sparc-climate.org/publications/sparc-reports/ (last access: 10 April 2018), 2017.

Hubert, D., Lambert, J.-C., Verhoelst, T., Granville, J., Keppens, A., Baray, J.-L., Bourassa, A. E., Cortesi, U., Degenstein, D. A., Froidevaux, L., Godin-Beekmann, S., Hoppel, K. W., Johnson, B. J., Kyrölä, E., Leblanc, T., Lichtenberg, G., Marchand, M., McElroy, C. T., Murtagh, D., Nakane, H., Portafaix, T., Querel, R., Russell III, J. M., Salvador, J., Smit, H. G. J., Stebel, K., Steinbrecht, W., Strawbridge, K. B., Stübi, R., Swart, D. P. J., Taha, G., Tarasick, D. W., Thompson, A. M., Urban, J., van Gijsel, J. A. E., Van Malderen, R., von der Gathen, P., Walker, K. A., Wolfram, E., and Zawodny, J. M.: Ground-based assessment of the bias and long-term stability of 14 limb and occultation ozone profile data records, Atmos. Meas. Tech., 9, 2497-2534, https://doi.org/10.5194/amt-9-2497-2016, 2016.

Jackman, C. H., Marsh, D. R., Vitt, F. M., Roble, R. G., Randall, C. E., Bernath, P. F., Funke, B., López-Puertas, M., Versick, S., Stiller, G. P., Tylka, A. J., and Fleming, E. L.: Northern Hemisphere atmospheric influence of the solar proton events and ground level enhancement in January 2005, Atmos. Chem. Phys., 11, 6153-6166, https://doi.org/10.5194/acp11-6153-2011, 2011.

Jackman, C. H., Marsh, D. R., Kinnison, D. E., Mertens, C. J., and Fleming, E. L.: Atmospheric changes caused by galactic cosmic rays over the period 1960-2010, Atmos. Chem. Phys., 16, 58535866, https://doi.org/10.5194/acp-16-5853-2016, 2016.

Kyrölä, E., Tamminen, J., Sofieva, V., Bertaux, J. L., Hauchecorne, A., Dalaudier, F., Fussen, D., Vanhellemont, F., Fanton D'Andon, O., Barrot, G., Guirlet, M., Fehr, T., and Saavedra de Miguel, L.: GOMOS $\mathrm{O}_{3}, \mathrm{NO}_{2}$, and $\mathrm{NO}_{3}$ observations in 2002-2008, Atmos. Chem. Phys., 10, 7723-7738, https://doi.org/10.5194/acp10-7723-2010, 2010a.

Kyrölä, E., Tamminen, J., Sofieva, V., Bertaux, J. L., Hauchecorne, A., Dalaudier, F., Fussen, D., Vanhellemont, F., Fanton D’Andon, O., Barrot, G., Guirlet, M., Mangin, A., Blanot, L., Fehr, T., Saavedra de Miguel, L., and Fraisse, R.: Retrieval of atmospheric parameters from GOMOS data, Atmos. Chem. Phys., 10, 1188111903, https://doi.org/10.5194/acp-10-11881-2010, 2010 b.

Kyrölä, E., Laine, M., Sofieva, V., Tamminen, J., Päivärinta, S.M., Tukiainen, S., Zawodny, J., and Thomason, L.: Combined SAGE II-GOMOS ozone profile data set for 1984-2011 and trend analysis of the vertical distribution of ozone, Atmos. Chem. Phys., 13, 10645-10658, https://doi.org/10.5194/acp-13-106452013, 2013.

Lary, D. J.: Catalytic destruction of stratospheric ozone, J. Geophys. Res., 102, 21515-21526, https://doi.org/10.1029/97JD00912, 1997.

Lean, J., Rottman, G., Harder, J., and Kopp, G.: SORCE Contributions to New Understanding of Global Change and Solar Variability, Solar Physics, 230, 27-53, https://doi.org/10.1007/s11207-005-1527-2, 2005.

Manney, G. L., Santee, M. L., Rex, M., Livesey, N. J., Pitts, M. C., Veefkind, P., Nash, E. R., Wohltmann, I., Lehmann, R., Froide- vaux, L., Poole, L. R., Schoeberl, M. R., Haffner, D. P., Davies, J., Dorokhov, V., Gernandt, H., Johnson, B., Kivi, R., Kyrö, E., Larsen, N., Levelt, P. F., Makshtas, A., McElroy, C. T., Nakajima, H., Parrondo, M. C., Tarasick, D. W., von der Gathen, P., Walker, K. A., and Zinoviev, N. S.: Unprecedented Arctic ozone loss in 2011, Nature, 478, 469-475, 2011.

Marchand, M., Bekki, S., Hauchecorne, A., and Bertaux, J.-L.: Validation of the self-consistency of GOMOS $\mathrm{NO}_{3}, \mathrm{NO}_{2}$ and $\mathrm{O}_{3}$ data using chemical data assimilation, Geophys. Res. Lett., 31, L10107, https://doi.org/10.1029/2004GL019631, 2004.

Marchand, M., Bekki, S., Lefevre, F., and Hauchecorne, A.: Temperature retrieval from stratospheric O3 and NO3 GOMOS data, Geophys. Res. Lett., 34, L24809, https://doi.org/10.1029/2007GL030280, 2007.

Marsh, D. R., Smith, A., Brasseur, G., Kaufmann, M., and Grossmann, K.: The existence of a tertiary ozone maximum in the high latitude middle mesosphere, Geophys. Res. Lett., 28, 4531-4534, 2001.

Marsh, D. R., Mills, M., Kinnison, D., Lamarque, J.-F., Calvo, N., and Polvani, L.: Climate change from 1850 to 2005 simulated in CESM1(WACCM), J. Climate, 26, 7372-7391, https://doi.org/10.1175/JCLI-D-12-00558.1, 2013.

Matthes, K., Funke, B., Andersson, M. E., Barnard, L., Beer, J., Charbonneau, P., Clilverd, M. A., Dudok de Wit, T., Haberreiter, M., Hendry, A., Jackman, C. H., Kretschmar, M., Kruschke, T., Kunze, M., Langematz, U., Marsh, D. R., Maycock, A., Misios, S., Rodger, C. J., Scaife, A. A., Seppälä, A., Shangguan, M., Sinnhuber, M., Tourpali, K., Usoskin, I., van de Kamp, M., Verronen, P. T., and Versick, S.: Solar Forcing for CMIP6, Geosci. Model Dev., 10, 2247-2302, https://doi.org/10.5194/gmd-102247-2017, 2017.

Meijer, Y. J., Swart, D. P. J., Allaart, M., Andersen, S. B., Bodeker, G., Boyd, I., Braathen, G., Calisesi, Y., Claude, H., Dorokhov, V., von der Gathen, P., Gil, M., Godin-Beekmann, S., Goutail, F., Hansen, G., Karpetchko, A., Keckhut, P., Kelder, H. M., Koelemeijer, R., Kois, B., Koopman, R. M., Kopp, G., Lambert, J.C., Leblanc, T., McDermid, I. S., Pal, S., Schets, H., Stubi, R., Suortti, T., Visconti, G., and Yela, M.: Pole-to-pole validation of Envisat GOMOS ozone profiles using data from ground-based and balloon sonde measurements, J. Geophys. Res.-Atmos., 109, D23305, https://doi.org/10.1029/2004JD004834, 2004.

Meinshausen, M., Smith, S. J., Calvin, K., Daniel, J. S., Kainuma, M. L. T., Lamarque, J. F., Matsumoto, K., Montzka, S. A., Raper, S. C. B., Riahi, K., Thomson, A., Velders, G. J. M., and van Vuuren, D. P. P.: The RCP greenhouse gas concentrations and their extensions from 1765 to 2300, Climatic Change, 109, 213-241, 2011.

Morgenstern, O., Hegglin, M. I., Rozanov, E., O'Connor, F. M., Abraham, N. L., Akiyoshi, H., Archibald, A. T., Bekki, S., Butchart, N., Chipperfield, M. P., Deushi, M., Dhomse, S. S., Garcia, R. R., Hardiman, S. C., Horowitz, L. W., Jöckel, P., Josse, B., Kinnison, D., Lin, M., Mancini, E., Manyin, M. E., Marchand, M., Marécal, V., Michou, M., Oman, L. D., Pitari, G., Plummer, D. A., Revell, L. E., Saint-Martin, D., Schofield, R., Stenke, A., Stone, K., Sudo, K., Tanaka, T. Y., Tilmes, S., Yamashita, Y., Yoshida, K., and Zeng, G.: Review of the global models used within phase 1 of the Chemistry-Climate Model Initiative (CCMI), Geosci. Model Dev., 10, 639-671, https://doi.org/10.5194/gmd-10-639-2017, 2017. 
Neale, R. B., Richter, J., Park, S., Lauritzen, P. H., Vavrus, S. J., Rasch, P. J., and Zhang, M.: The Mean Climate of the Community Atmosphere Model (CAM4) in Forced SST and Fully Coupled Experiments, J. Climate, 26, 5150-5168, https://doi.org/10.1175/JCLI-D-12-00236.1, 2013.

Päivärinta, S.-M., Verronen, P. T., Funke, B., Gardini, A., Seppälä, A., and Andersson, M. E.: Transport versus energetic particle precipitation: Northern polar stratospheric $\mathrm{NO}_{x}$ and ozone in January-March 2012, J. Geophys. Res.-Atmos., 121, 60856100, https://doi.org/10.1002/2015JD024217, 2016.

Randall, C. E., Harvey, V. L., Siskind, D. E., France, J., Bernath, P. F., Boone, C. D., and Walker, K. A.: $\mathrm{NO}_{x}$ descent in the Arctic middle atmosphere in early 2009, Geophys. Res. Lett., 36, L18811, https://doi.org/10.1029/2009GL039706, 2009.

Randall, C. E., Harvey, V. L., Holt, L. A., Marsh, D. R., Kinnison, D., Funke, B., and Bernath, P. F.: Simulation of energetic particle precipitation effects during the 20032004 Arctic winter, J. Geophys. Res.-Space, 120, 5035-5048, https://doi.org/10.1002/2015JA021196, 2015.

Renard, J., Berthet, G., Brogniez, C., Catoire, V., Fussen, D., Goutail, F., Oelhaf, H., Pommereau, J., Roscoe, H. K., Wetzel, G., Chartier, M., Robert, C., Balois, J., Verwaerde, C., Auriol, F., François, P., Gaubicher, B., and Wursteisen, P.: Validation of GOMOS-Envisat vertical profiles of $\mathrm{O}_{3}, \mathrm{NO}_{2}, \mathrm{NO}_{3}$, and aerosol extinction using balloon-borne instruments and analysis of the retrievals, J. Geophys. Res.-Space, 113, A02302, https://doi.org/10.1029/2007JA012345, 2008.

Rienecker, M. M., Suarez, M. J., Gelaro, R., Todling, R., Bacmeister, J., Liu, E., Bosilovich, M. G., Schubert, S. D., Takacs, L., Kim, G.-K., Bloom, S., Chen, J., Collins, D., Conaty, A., da Silva, A., Gu, W., Joiner, J., Koster, R. D., Lucchesi, R., Molod, A., Owens, T., Pawson, S., Pegion, P., Redder, C. R., Reichle, R., Robertson, F. R., Ruddick, A. G., Sienkiewicz, M., and Woollen, J.: MERRA: NASA's Modern-Era Retrospective Analysis for Research and Applications, J. Climate, 24, 3624-3648, https://doi.org/10.1175/JCLI-D-11-00015.1, 2011.

Sakazaki, T., Shiotani, M., Suzuki, M., Kinnison, D., Zawodny, J. M., McHugh, M., and Walker, K. A.: Sunset-sunrise difference in solar occultation ozone measurements (SAGE II, HALOE, and ACE-FTS) and its relationship to tidal vertical winds, Atmos. Chem. Phys., 15, 829-843, https://doi.org/10.5194/acp-15-8292015, 2015.

Schmidt, H., Brasseur, G. P., Charron, M., Manzini, E., Giorgetta, M. A., Diehl, T., Fomichev, V. I., Kinnison, D., Marsh, D., and Walters, S.: The HAMMONIA chemistry climate model: Sensitivity of the mesopause region to the 11-year solar cycle and $\mathrm{CO}_{2}$ doubling, J. Climate, 19, 3903-3931, 2006.

Seppälä, A., Verronen, P. T., Kyrölä, E., Hassinen, S., Backman, L., Hauchecorne, A., Bertaux, J. L., and Fussen, D.: Solar proton events of October-November 2003: Ozone depletion in the Northern Hemisphere polar winter as seen by GOMOS/Envisat, Geophys. Res. Lett., 31, L19107, https://doi.org/10.1029/2004GL021042, 2004.

Seppälä, A., Verronen, P. T., Clilverd, M. A., Randall, C. E., Tamminen, J., Sofieva, V. F., Backman, L., and Kyrölä, E.: Arctic and Antarctic polar winter $\mathrm{NO}_{x}$ and energetic particle precipitation in 2002-2006, Geophys. Res. Lett., 34, L12810, https://doi.org/10.1029/2007GL029733, 2007.
Sheese, P. E., Walker, K. A., Boone, C. D., McLinden, C. A., Bernath, P. F., Bourassa, A. E., Burrows, J. P., Degenstein, D. A., Funke, B., Fussen, D., Manney, G. L., McElroy, C. T., Murtagh, D., Randall, C. E., Raspollini, P., Rozanov, A., Russell III, J. M., Suzuki, M., Shiotani, M., Urban, J., von Clarmann, T., and Zawodny, J. M.: Validation of ACE-FTS version $3.5 \mathrm{NO}_{y}$ species profiles using correlative satellite measurements, Atmos. Meas. Tech., 9, 5781-5810, https://doi.org/10.5194/amt-9-5781-2016, 2016.

Smith, A. K., Marsh, D. R., Russell, J. M., Mlynczak, M. G., Martin-Torres, F. J., and Kyrölä, E.: Satellite observations of high nighttime ozone at the equatorial mesopause, J. Geophys. Res.Atmos., 113, D17312, https://doi.org/10.1029/2008JD010066, 2008.

Smith, A. K., López-Puertas, M., García-Comas, M., and Tukiainen, S.: SABER observations of mesospheric ozone during NH late winter 2002-2009, Geophys. Res. Lett., 36, L23804, https://doi.org/10.1029/2009GL040942, 2009.

Smith, A. K., Rolando, R. R., Marsh, D. R., and Richter, J. H.: WACCM simulations of the mean circulation and trace species transport in the winter mesosphere, J. Geophys. Res., 116, D20115, https://doi.org/10.1029/2011JD016083, 2011.

Smith, A. K., Harvey, V. L., Mlynczak, M. G., Funke, B., GarcíA-Comas, M., Hervig, M., Kaufmann, M., Kyrölä, E., López-Puertas, M., McDade, I., Randall, C. E., Russell, J. M., Sheese, P. E., Shiotani, M., Skinner, W. R., Suzuki, M., and Walker, K. A.: Satellite observations of ozone in the upper mesosphere, J. Geophys. Res.-Atmos., 118, 5803-5821, https://doi.org/10.1002/jgrd.50445, 2013.

Smith, A. K., Lopez-Puertas, M., Funke, B., Garcia-Comas, M., Mlynczak, M. G., and Holt, L. A.: Nighttime ozone variability in the high latitude winter mesosphere, J. Geophys. Res.-Atmos., 119, 13547-13564, https://doi.org/10.1002/2014JD021987, 2014.

Sofieva, V. F., Kyrölä, E., Verronen, P. T., Seppälä, A., Tamminen, J., Marsh, D. R., Smith, A. K., Bertaux, J.-L., Hauchecorne, A., Dalaudier, F., Fussen, D., Vanhellemont, F., Fanton d'Andon, O., Barrot, G., Guirlet, M., Fehr, T., and Saavedra, L.: Spatiotemporal observations of the tertiary ozone maximum, Atmos. Chem. Phys., 9, 4439-4445, https://doi.org/10.5194/acp-9-44392009, 2009.

Sofieva, V. F., Kalakoski, N., Verronen, P. T., Päivärinta, S.M., Kyrölä, E., Backman, L., and Tamminen, J.: Polar-night $\mathrm{O}_{3}, \mathrm{NO}_{2}$ and $\mathrm{NO}_{3}$ distributions during sudden stratospheric warmings in 2003-2008 as seen by GOMOS/Envisat, Atmos. Chem. Phys., 12, 1051-1066, https://doi.org/10.5194/acp-121051-2012, 2012.

Sofieva, V. F., Ialongo, I., Hakkarainen, J., Kyrölä, E., Tamminen, J., Laine, M., Hubert, D., Hauchecorne, A., Dalaudier, F., Bertaux, J.-L., Fussen, D., Blanot, L., Barrot, G., and Dehn, A.: Improved GOMOS/Envisat ozone retrievals in the upper troposphere and the lower stratosphere, Atmos. Meas. Tech., 10, 231246, https://doi.org/10.5194/amt-10-231-2017, 2017.

Solomon, S.: Stratospheric ozone depletion: a review of concepts and history, Rev. Geophys., 37, 275-316, 1999.

Tamminen, J., Kyrölä, E., Sofieva, V. F., Laine, M., Bertaux, J., Hauchecorne, A., Dalaudier, F., Fussen, D., Vanhellemont, F., Fanton-D'Andon, O., Barrot, G., Mangin, A., Guirlet, M., Blanot, L., Fehr, T., Saavedra de Miguel, L., and Fraisse, R.: 
GOMOS data characterisation and error estimation, Atmos. Chem. Phys., 10, 9505-9519, https://doi.org/10.5194/acp-109505-2010, 2010.

Tegtmeier, S., Hegglin, M. I., Anderson, J., Bourassa, A., Brohede, S., Degenstein, D., Froidevaux, L., Fuller, R., Funke, B., Gille, J., Jones, A., Kasai, Y., Krüger, K., Kyrölä, E., Lingenfelser, G., Lumpe, J., Nardi, B., Neu, J., Pendlebury, D., Remsberg, E., Rozanov, A., Smith, L., Toohey, M., Urban, J., Clarmann, T., Walker, K. A., and Wang, R. H. J.: SPARC Data Initiative: A comparison of ozone climatologies from international satellite limb sounders, J. Geophys. Res.-Atmos., 118, 12229, https://doi.org/10.1002/2013JD019877, 2013.

Tilmes, S., Lamarque, J.-F., Emmons, L. K., Kinnison, D. E., Marsh, D., Garcia, R. R., Smith, A. K., Neely, R. R., Conley, A., Vitt, F., Val Martin, M., Tanimoto, H., Simpson, I., Blake, D. R., and Blake, N.: Representation of the Community Earth System Model (CESM1) CAM4-chem within the ChemistryClimate Model Initiative (CCMI), Geosci. Model Dev., 9, 18531890, https://doi.org/10.5194/gmd-9-1853-2016, 2016.

Tukiainen, S., Kyrölä, E., Verronen, P. T., Fussen, D., Blanot, L., Barrot, G., Hauchecorne, A., and Lloyd, N.: Retrieval of ozone profiles from GOMOS limb scattered measurements, Atmos. Meas. Tech., 4, 659-667, https://doi.org/10.5194/amt-4659-2011, 2011.

Tukiainen, S., Kyrölä, E., Tamminen, J., Kujanpää, J., and Blanot, L.: GOMOS bright limb ozone data set, Atmos. Meas. Tech., 8, 3107-3115, https://doi.org/10.5194/amt-8-3107-2015, 2015.

Tweedy, O. V., Limpasuvan, V., Orsolini, Y. J., Smith, A. K., Garcia, R. R., Kinnison, D., Randall, C. E., Kvissel, O.-K., Stordal, F., Harvey, V. L., and Chandran, A.: Nighttime secondary ozone layer during major stratospheric sudden warmings in specifieddynamics WACCM, J. Geophys. Res.-Atmos., 118, 8346-8358, https://doi.org/10.1002/jgrd.50651, 2013.

van de Kamp, M., Seppälä, A., Clilverd, M. A., Rodger, C. J., Verronen, P. T., and Whittaker, I. C.: A model providing longterm datasets of energetic electron precipitation during geomagnetic storms, J. Geophys. Res.-Atmos., 121, 12520-12540, https://doi.org/10.1002/2015JD024212, 2016. van Gijsel, J. A. E., Swart, D. P. J., Baray, J.-L., Bencherif, H., Claude, H., Fehr, T., Godin-Beekmann, S., Hansen, G. H., Keckhut, P., Leblanc, T., McDermid, I. S., Meijer, Y. J., Nakane, H., Quel, E. J., Stebel, K., Steinbrecht, W., Strawbridge, K. B., Tatarov, B. I., and Wolfram, E. A.: GOMOS ozone profile validation using ground-based and balloon sonde measurements, Atmos. Chem. Phys., 10, 10473-10488, https://doi.org/10.5194/acp-10-10473-2010, 2010.

Verronen, P. T., Kyrölä, E., Tamminen, J., Funke, B., Gil-López, S., Kaufmann, M., López-Puertas, M., von Clarmann, T., Stiller, G., Grabowski, U., and Höpfner, M.: A comparison of nighttime GOMOS and MIPAS ozone profiles in the stratosphere and mesosphere, Adv. Space Res., 36, 958-966, 2005.

Verronen, P. T., Kyrölä, E., Tamminen, J., Sofieva, V. F., Clarmann, T., Stiller, G. P., Kaufmann, M., López-Puertas, M., Funke, B., and Bermejo-Pantaleon, D.: A Comparison of Daytime and Night-Time Ozone Profiles from GOMOS and MIPAS, in: Proceedings of the Envisat Symposium 2007, Montreux, Switzerland, Vol. ESA SP-636, European Space Agency, available at: http://envisat.esa.int/workshops/envisatsymposium/proceedings/ sessions/2A3/462479bv.pdf (last access: 16 March 2018), 2007.

Verronen, P. T., Ceccherini, S., Cortesi, U., Kyrölä, E., and Tamminen, J.: Statistical comparison of night-time $\mathrm{NO}_{2}$ observations in 2003-2006 from GOMOS and MIPAS instruments, Adv. Space Res., 43, 1918-1925, https://doi.org/10.1016/j.asr.2009.01.027, 2009.

Verronen, P. T., Andersson, M. E., Marsh, D. R., Kovács, T., and Plane, J. M. C.: WACCM-D - Whole Atmosphere Community Climate Model with D-region ion chemistry, J. Adv. Model. Earth Syst., 8, 954-975, https://doi.org/10.1002/2015MS000592, 2016. 